\title{
Tropical fungi: twelve species of lignicolous Ascomycota from the Dominican Republic
}

\author{
Angelini $\mathrm{C}^{{ }^{*}}$ and Medardi $\mathrm{G}^{2}$ \\ ${ }^{1}$ Via Tulipifero, 9 - I - 33080 Porcia (Pordenone) - E-mail: claudio_angelini@libero.it \\ ${ }^{2}$ Via G. Mazzini, 21 - I - 25086 Rezzato (Brescia) - E-mail: gianfranco.medardi@gmail.com
}

Angelini C, Medardi G 2012 - Tropical fungi: twelve species of lignicolous Ascomycota from the Dominican Republic. Mycosphere 3(5), 567-601, Doi 10.5943/mycosphere/3/5/6

Twelve lignicolous interesting Ascomycota from the Dominican Republic collected during the winter period (November-January) in the years 2008-2011 are described and illustrated.

Key words - Pezizomycetes - Pezizomycotina - Sordariomycetes - Sub-tropical zone Caribbeans - Taxonomy

\section{Article Information}

Received 4 August 2012

Accepted 13 August 2012

Published online 25 September 2012

*Corresponding author: Claudio Angelini - e-mail - claudio_angelini@libero.it

\section{Introduction}

Over the past six years, one of the authors (C.A.) has studied tropical fungi in Dominican Republic collecting what he could find during short vacations. To date, he has managed to photograph in habitat, dry and study more than 200 species of macrofungi, of which about half have already been determined and deposited in the herbarium of the Botanical Garden of Santo Domingo (Jardín Botánico Nacional dr. Rafael Ma. Moscoso - Santo Domingo - Dominican Republic). Approximately $10 \%$ of the collections are Ascomycota.

These fungi seem to be more common and numerous in anthropic areas, near cities or villages where fruit trees are cultivated or where woody residuals laying on the ground are rather copious. Protected areas and reserves not rarely contain only one or a few tree species; this lack of diversity, often together with environmental conditions, make these areas unfavourable for saprotrophic ascomycetes. Common trees in this kind of environment are evergreen or deciduous frondose trees; conifers are not present, but are found in restricted areas of reforestation or in natural controlled reserves.

Areas of research and collection were widespread at various altitudinal levels: the coastal environment (Sosúa, P.to Plata), where for the most part the vegetation immediately behind the beaches consists of trees of the genera Bucida, Bursera, Calophyllum, Coccoloba, Guazuma, Hura, Ocotea, Roystonea, Samanea, Swietenia, Terminalia, and the ever present Cocos; along the many rivers, streams and small rivers in the same area of Sosúa, P.to Plata, where the trees mostly belong to the genera Andira, Artocarpus, Bursera, Cecropia, Dendropanax, Hura, Inga, Mangifera, Hymenaea; the area of riparian woodland located along the river S. Juan, in the municipality of Rio S. Juan (Marìa Trinidad Sànchez province), where there are often the same species as above (with the exception of Swietenia) or other, typical of that area, as for example Amphitecna, Ficus, Guarea, Guazuma, Lonchocarpus, Pterocarpus and Spondias; the mountainous region of Jarabacoa where the vegetation consists mainly 


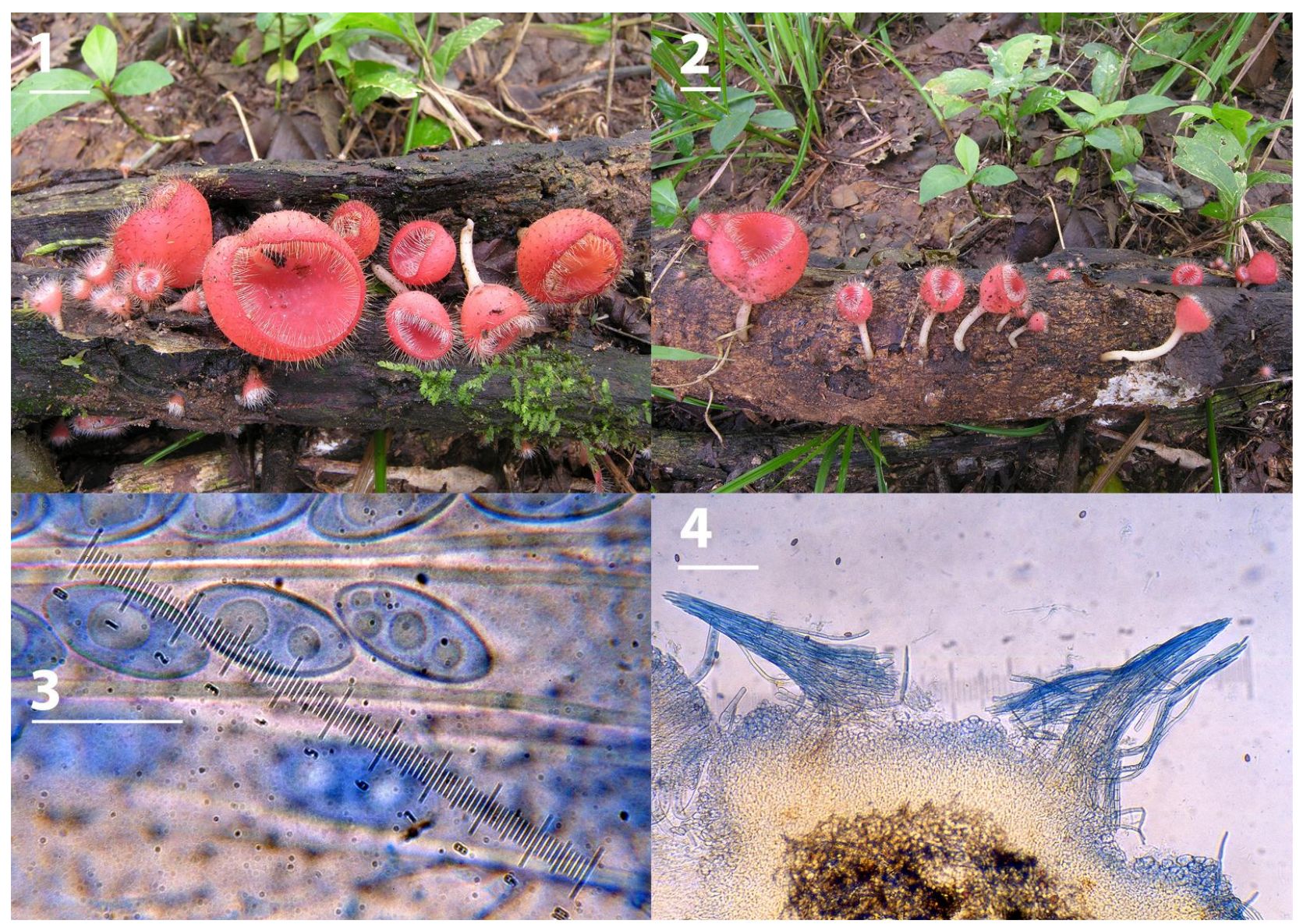

Figs 1-4 - Cookeina sulcipes. 1, 2 Apothecia in environment. 3 Spores (coloured with lactic blue). 4 Hairs (coloured with lactic blue). Bars figs 1, $2=1 \mathrm{~cm}-$ fig $3=25 \mu \mathrm{m}-$ fig $4=800 \mu \mathrm{m}$.

of deciduous forests and pine (Pinus occidentalis).

\section{Methods}

Fungi were photographed in the fresh state in situ, using a digital camera Nikon coolpix 8400, and then dried using a dryer. Microscopic examinations were carried out on dried specimens rehydrated in water. Specimens were studied morphologically using an Optika optical microscope (BK 1301 model). Mounts were made in water; Melzer's reagent and cotton blue in lactic acid were used to verify eventual amyloid reactions of the asci and to appreciate the spore ornamentation. Photos in environment are by C.A.; drawings and micro-photos are by G.M.

\section{Description of the species}

Cookeina sulcipes (Berk.) Kunze, Revis. Gen. Pl. 2: 849 (1891)
Basionym: Peziza sulcipes Berk., London J. Bot. 1: 141 (1842)

$\equiv$ Trichoscypha sulcipes (Berk.) Cooke, Syll. Fung. 8: 161 (1889)

$\equiv$ Pilocratera sulcipes (Berk.) Sacc. \& Traverso, Syll. Fung. 20: 413 (1911)

Apothecia rather deeply cup-shaped (up to $10 \mathrm{~mm}$ ), 5-20 $\mathrm{mm}$ diam. and up to $30 \mathrm{~mm}$ high, stalked, funnel-shaped. Hymenial surface smooth, orange-red to cherry-red, scarlet red. Outer surface with long whitish hairs, considerably dense near the margin and grouped in tufts, concolorous to the hymenial surface, often with rough, wrinkled or folded aspect; margin regular, whole, densely hairy, showing a few concentric rings. Stalk variably long, cylindrical, only slightly enlarged at the top where it connects to the cup, 2-3.5 mm diam., whitish cream with delicate orange reflections, initially smooth, but feebly longitudinally furrowed in adults. Flesh waxy, fragile, pale whitish orange. 

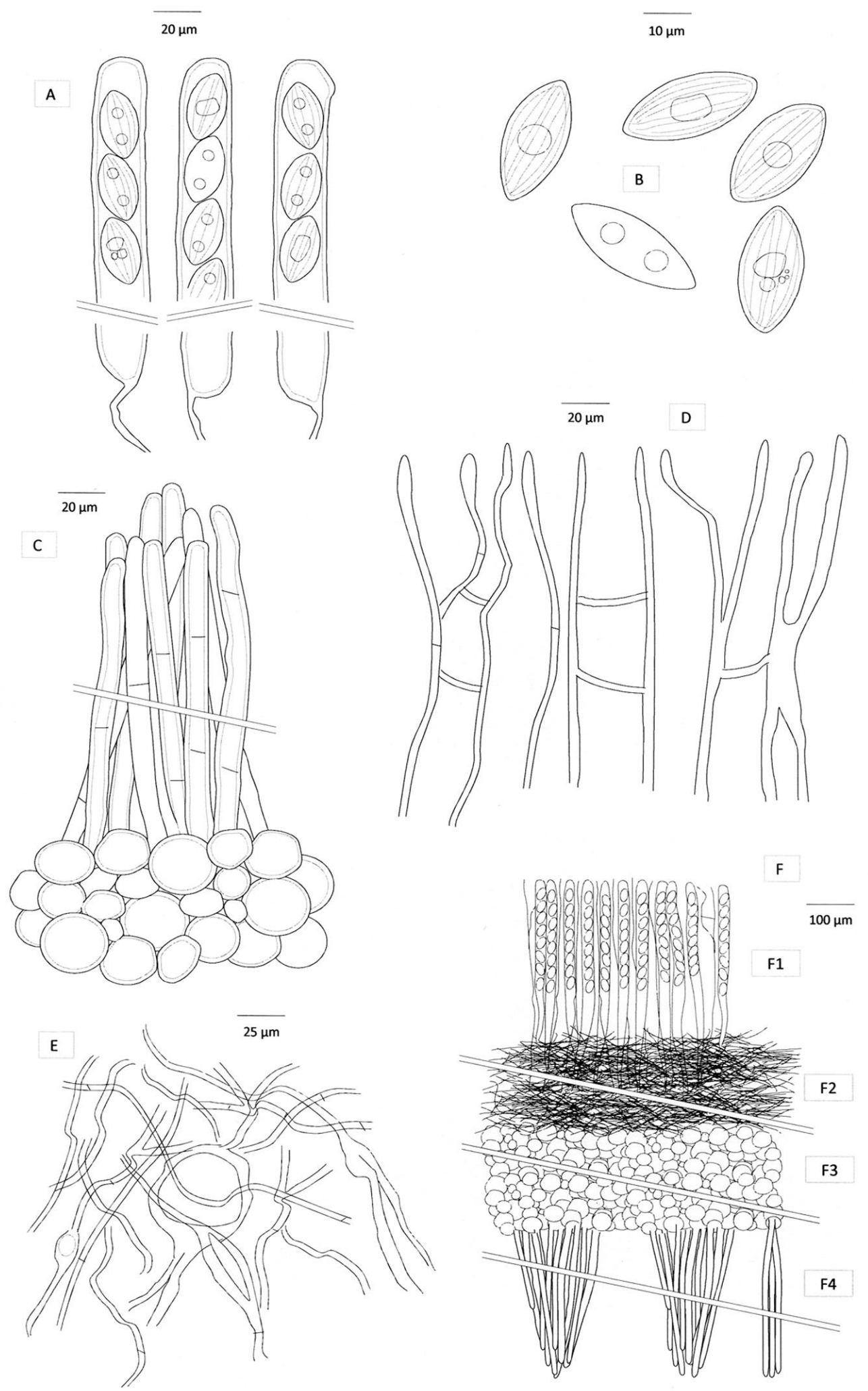

Fig. 5 - Cookeina sulcipes. A Asci with ascospores. B Released ascospores. C Hairs (detail). D Paraphyses. E Medullar excipulum (detail). F Vertical section (F1 Hymenium - F2 Medullar excipulum - F3 Ectal excipulum - F4 Hairs). 
Ascospores 27-30 × 12-13.5(-14.5) $\mu \mathrm{m}[27-33 \times 14-18 \mu \mathrm{m}$, Seaver 1928; 29-31 × 15-18 $\mu \mathrm{m}$, Le Gal 1953], fusiform or ellipsoidal-fusiform, showing 15-20 thin striations more or less parallel and straight, thick-walled (up to $3 \mu \mathrm{m}$ ), with 1-2 rounded or deformed oil-drops, hyaline, uniseriate in the asci. Spore wall barely visible with $\mathrm{KOH}$. Asci 340-380 × 18-20 (23) $\mu \mathrm{m}$, cylindrical, thickwalled (up to $3 \mu \mathrm{m}$ ), sometimes swollen in some points (also near the apex), with abruptly tapered base ending in a thin and often bent "tail" 15-30 $\mu \mathrm{m}$ long, non-amyloid, suboperculate, 8-spored. Paraphyses 2-2.5 $\mu \mathrm{m}$ diam., thread-like, cylindrical, some long forked, others simple, the most part anastomosed even more than once. Subhymenium not obvious. Medullar excipulum 200-300 $\mu \mathrm{m}$ thick; textura intricata, hyphae 5-6 $\mu \mathrm{m}$ diam. (some elements swollen up to $9 \mu \mathrm{m}$ ), rather interwoven, septate, variously anastomosed, hyaline or slightly yellowish. Ectal excipulum 200-300 $\mu \mathrm{m}$ thick; textura globulosa, cells 20-30 $\mu \mathrm{m}$ diam., rounded (rarely angular), globose or slightly ellipsoidal $(13-20 \times 10-16 \mu \mathrm{m})$, thick-walled, yellowish or yellow-brownish. Bundles of hairs up to $2000 \mu \mathrm{m}$ long, $40-50 \mu \mathrm{m}$ wide at the top and $100-130 \mu \mathrm{m}$ at the base, arising from the medullar excipulum, made up of strictly fenced hyphae, 9-13 $\mu \mathrm{m}$ wide and thick-walled (up to $3 \mu \mathrm{m})$, cylindrical, with rounded apex, septate, yellowish or pale brownish-yellow. Hyphae less numerous at the top and more dense (and shorter) at the base, giving the hair its characteristic triangular outline.

Habitat - in groups of more or less close ascocarps, on hard degraded wood of frondose tropical / equatorial trees; Le Gal (1953): also on decomposed wood lying in humous soil. November to April.

Specimens examined - Dominican Republic, Rio S. Juan, 2 specimens on decaying tropical wood of deciduous trees, 23 Dec 2010, C. Angelini, JBSD 121935; Dominican Republic, Sosua, P.to Plata, locality Puerto Chiquito, 15 specimens on decaying tropical wood of deciduous trees, 25 Nov 2011, C. Angelini, exsiccatum in personal herbarium of one of the authors (C.A.) before being deposited in JBSD.

\section{Discussion}

The genus Cookeina Kunze consists of lignicolous or humicolous species widespread in tropical or equatorial areas, funnel-shaped, usually brightly coloured, with or without long hairs, producing ascospores with or without longitudinal stripes. Other important characteristics are the particular architecture of the hair consisting of more or less parallel and fasciculate hyphae, the conformation of the base of the asci which ends abruptly in a more or less long rooting appendage, and the paraphyses joined by a variety of anastomosis at different heights, which together can be compared to a single tissue with loose texture. The suboperculate asci determine membership in the family Sarcoscyphaceae Le Gal ex Eckblad.

C. tricholoma (Mont.) Kunze fruits in the same environments; it has the same structural features, but it differs in having generally paler apothecia (watery orangeyellow or pale pink-orange), and larger ascospores $(32-35 \times 14-15 \mu \mathrm{m})$, with the same type of ornamentation. Also C. speciosa (Fr. : Fr.) Dennis has similar apothecia, but hairs originating from the ectal excipulum; it has yellow-orange, grey-brown to evenly chocolate-brown hymenial surface, slightly paler outer surface, and ascospores (22-)24-33 $\times \quad(10-) 12-16 \mu \mathrm{m}$, showing longitudinal striations (Wang 1997) not perfectly straight, but more or less sinuous, as appears in the SEM image in Weinstein \& Pfister (2002). $C$. sinensis Zheng Wang and $C$. insititia (Berk. \& M.A. Curtis) Kunze [= Pilocratera insititia (Berk. \& M.A. Curtis) Sacc. \& Traverso] form ascocarps with similar features. The former has apothecia with orange-pink hymenial surface and pale pink outer surface, watery brown or whitish hairs that originate from medullar excipulum, and ascospores 27-27.5 × 13-15 $\mu \mathrm{m}$, with fine, irregular longitudinal striations (Wang 2001); the latter forms apothecia with whitish to yellowish pink hymenial surface and pale brown outer surface, white hairs originating from the ectal excipulum, and fusiform and more or less one side flattened 


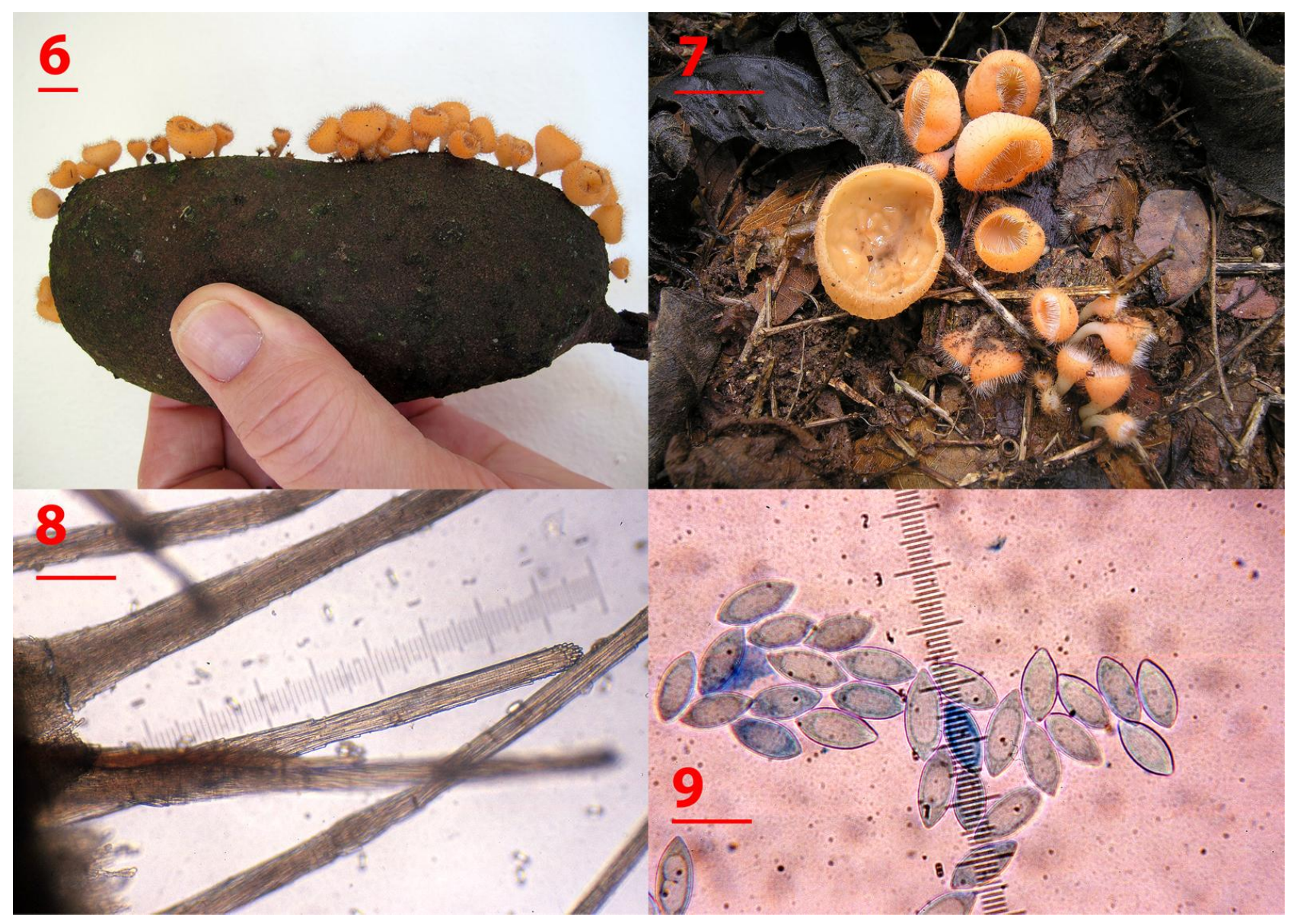

Figs 6-9 - Cookeina tricholoma. 6, 7 Apothecia in environment [6, apothecia on algarroba or "cica en cajeta" (fruit of Hymenaea courbaril)]. 8 Hairs (coloured with lactic blue). 9 Spores (coloured with lactic blue). - Bars figs $6,7=1 \mathrm{~cm}-$ fig $8=200 \mu \mathrm{m}-$ fig $9=30 \mu \mathrm{m}$.

ascospores, 40-55 × 10-11 $\mu \mathrm{m}$ (Wang 2001)

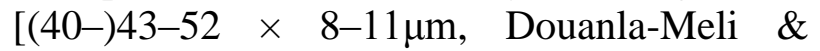
Langer 2005], apparently smooth under the optical microscope, but finely warted under SEM.

Some Cookeina are glabrous. $C$. colensoi (Berk.) Seaver produces sub-stalked apothecia, evenly yellow-brown or orangebrown, with smooth ascospores 28-34 × 11-15 $\mu \mathrm{m}[30-40 \times 12-15 \mu \mathrm{m}$, Seaver 1928; 32-38 × 13-14 $\mu \mathrm{m}$, Le Gal 1953], while $C$. indica Pfister \& R. Kaushal has entirely yellow apothecia, with outer surface furfuraceous only near the margin, and ascospores 26.5-34.2 $\times$ 10-11.5 $\mu \mathrm{m}$, equipped with a fine longitudinal striation (Pfister \& Kaushal 1984). C. venezuelae (Berk. \& M.A. Curtis) Le Gal, terricolous, is instead sessile; it has orange hymenial surface, paler outer surface, and smooth ascospores, 30-33 $\times$ 10-12 $\mu \mathrm{m}$
(Saccardo et al. 1889). C. globosa DouanlaMeli, also lignicolous, has uniformly pink or pale red stalked apothecia, velvety on the outer surface, and produces ascospores smooth, thinwalled and significantly smaller, (11) 12-15(16) $\times(9-) 10-12 \mu \mathrm{m}$ (Douanla-Meli \& Langer 2005).

The genus Geodina Denison currently consists of a single species (G. guanacastensis Denison), with an appearance resembling that of Cookeina; it shares with Cookeina the suboperculate asci, the shape of the hair and the architecture of the flesh, but it is distinguished by some constant characters, such as the base of the asci being long tapered, the paraphyses more or less club shaped and poorly anastomosed only in the lower part, and the ascospores showing large, straight to curved ribs, often jointed into an incomplete, more or less opened portions of reticulum. $G$. 

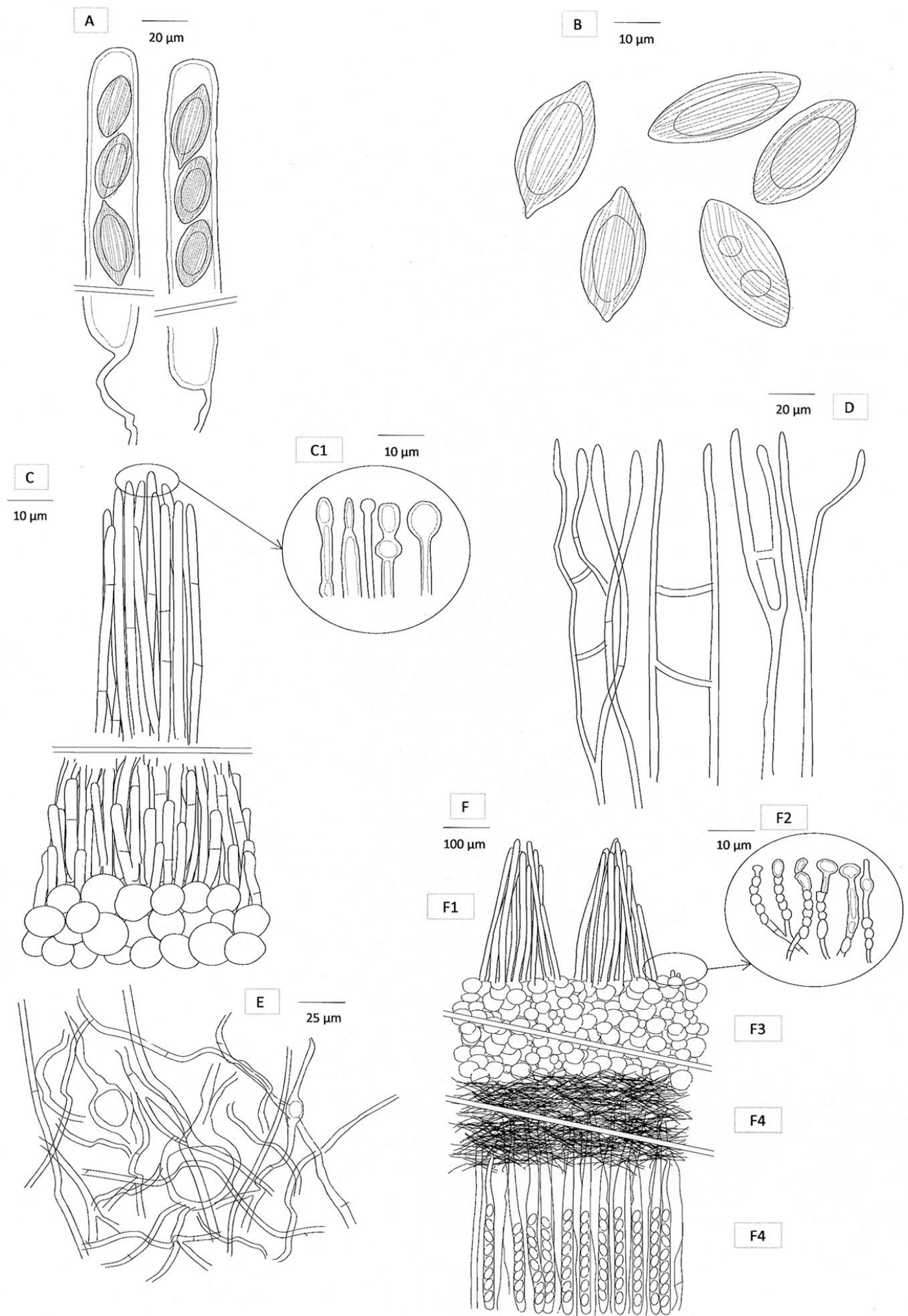

Fig. 10 - Cookeina tricholoma. A Asci with ascospores. B Released ascospores. C Hairs (C1 details of the top). D Paraphyses. E Medullar excipulum (details). F Vertical section (F1 Hairs - F2 Marginal cells - F3 Medullar excipulum - F4 Hymenium). 
guanacastensis forms apothecia supported by a very thin stalk, with pale orange to pale yellow-orange hymenial surface, outer surface concolorous, but appearing darker because covered with dark brown hairs; it forms ascospores $22-25 \times 11-13 \mu \mathrm{m}$ and fruits on bare soil (Denison 1965).

Cookeina tricholoma (Mont.) Kunze, Revis. Gen. Pl. 2: 849 (1891) Figs 6-10 Basionym: Peziza tricholoma Mont., Ann. Sci. Nat. Bot. 2: 77 (t 4:2) (1834)

$\equiv$ Trichoscypha tricholoma (Mont.) Cooke, Syll. Fung. 8: 160 (1889)

$\equiv$ Pilocratera tricholoma (Mont.) Henn., Monsunia 1: tab. 1 (1900)

Apothecia quite deeply cup-shaped (up to $10 \mathrm{~mm}$ ), 5-15 $\mathrm{mm}$ diam. and up to $40 \mathrm{~mm}$ high, more or less long stalked, funnel-shaped. Hymenial surface smooth, pale yellow-orange, pale pink-orange to orange-reddish in wet specimens. Outer surface provided with long, whitish or very faintly orange-brown hairs, markedly denser at the margin, also grouped in bundles, concolorous to the hymenial surface, sometimes rough; margin smooth, whole, often introflexed, densely hairy. Stalk variably long, cylindrical, slightly dilated at the top where it connects to the cup, about $2 \mathrm{~mm}$ diam., smooth, white-cream with vague orange reflexes. Flesh waxy, whitish or very pale whitish-orange.

Ascospores quite variable in size, $32-$ $35 \times 14-15 \mu \mathrm{m}[27-33 \times 12-14 \mu \mathrm{m}$, Seaver 1928; 25-35 × 11-13.5 $\mu \mathrm{m}$, Wang 1997; (18.5-)20-33 × (8.5-)11-15 $\mu \mathrm{m}$, DouanlaMeli \& Langer 2005], fusiform, some irregularly citriform, sometimes with slightly mucronate extremities, with 15-20 longitudinal thin striations, straight and more or less parallel, wall up to $2 \mu \mathrm{m}$ thick, generally with a large cylindrical-ellipsoidal oil drop, infrequently 2 oil-drops, hyaline, uniseriate in the asci. Asci 330-400 $\times$ 15-20 $\mu \mathrm{m}$, cylindrical, wall $1.5-2 \mu \mathrm{m}$ thick, with abruptly tapered base that ends in a thin and usually curved appendage 15-35 $\mu \mathrm{m}$ long, not amyloid, suboperculate, 8-spored. Paraphyses 2-2.5 $\mu \mathrm{m}$ diam. (up to $4 \mu \mathrm{m}$ in some points), thread-like, cylindrical, simple or pluri-forked, often several times anastomosed by more or less transversal or oblique septa, with granular contents. Subhymenium not obvious. Medullar excipulum 250-300 $\mu \mathrm{m}$ thick; textura intricata, hyphae of 5-8 $\mu \mathrm{m}$ diam. (some elements up to $10 \mu \mathrm{m}$ large), interwoven, variously anastomosed, septate, hyaline or slightly yellowish. Ectal excipulum 300-350 $\mu$ m thick; textura globulosa, cells 20-30 $\mu \mathrm{m}$ diam., rounded (only in a few cases angular), globose or slightly ellipsoidal (and then 15-20 × 12-18 $\mu \mathrm{m})$, wall thin or slightly thickened, greybrown or pale brown. Presence of catenulate marginal cells, apex irregularly shaped or enlarged up to 5-6 $\mu \mathrm{m}$, up to $35 \mu \mathrm{m}$ long. Hairs up to $2500 \mu \mathrm{m}$ long, 40-45(-50) $\mu \mathrm{m}$ large at the apex and 100-130 $\mu \mathrm{m}$ at the base, arising from the medullar excipulum, formed by more or less parallel fenced hyphae 9-13 $\mu \mathrm{m}$ wide, cylindrical or slightly enlarged in some points, with rounded, capitulate tip, irregularly thickened in some points, wall 2.$3.5 \mu \mathrm{m}$ thick, septate, yellow-brown, less dense near the top and more numerous and shorter near the base, defining the triangular outline of the hair.

Habitat - in groups of more or less close fruit-bodies, usually on decaying wood of frondose tropical / equatorial trees, November to April.

Specimens examined - Dominican Republic, Sosua, P.to Plata, 25 specimens on degraded wood of tropical deciduous trees, 18 Jan 2011, C. Angelini, JBSD 121913; Dominican Republic, Sosua, P.to Plata, 12 specimens on degraded wood of tropical deciduous trees, 4 Dec 2011, C. Angelini, exsiccatum in personal herbarium of one of the authors (C.A.) before being deposited in JBSD.

\section{Discussion}

The main identifying characters of $C$. tricholoma are the pale yellow-orange apothecia and the large ascospores. However, particularly colourful specimens of $C$. sulcipes (Berk.) Kunze, usually orange-red, cherry-red or scarlet, may at first be confused with $C$. tricholoma; its ascospores, although with the same kind of ornamentation, are smaller [27$30 \times 12-13.5(14.5) \mu \mathrm{m}]$. A peculiarity we 


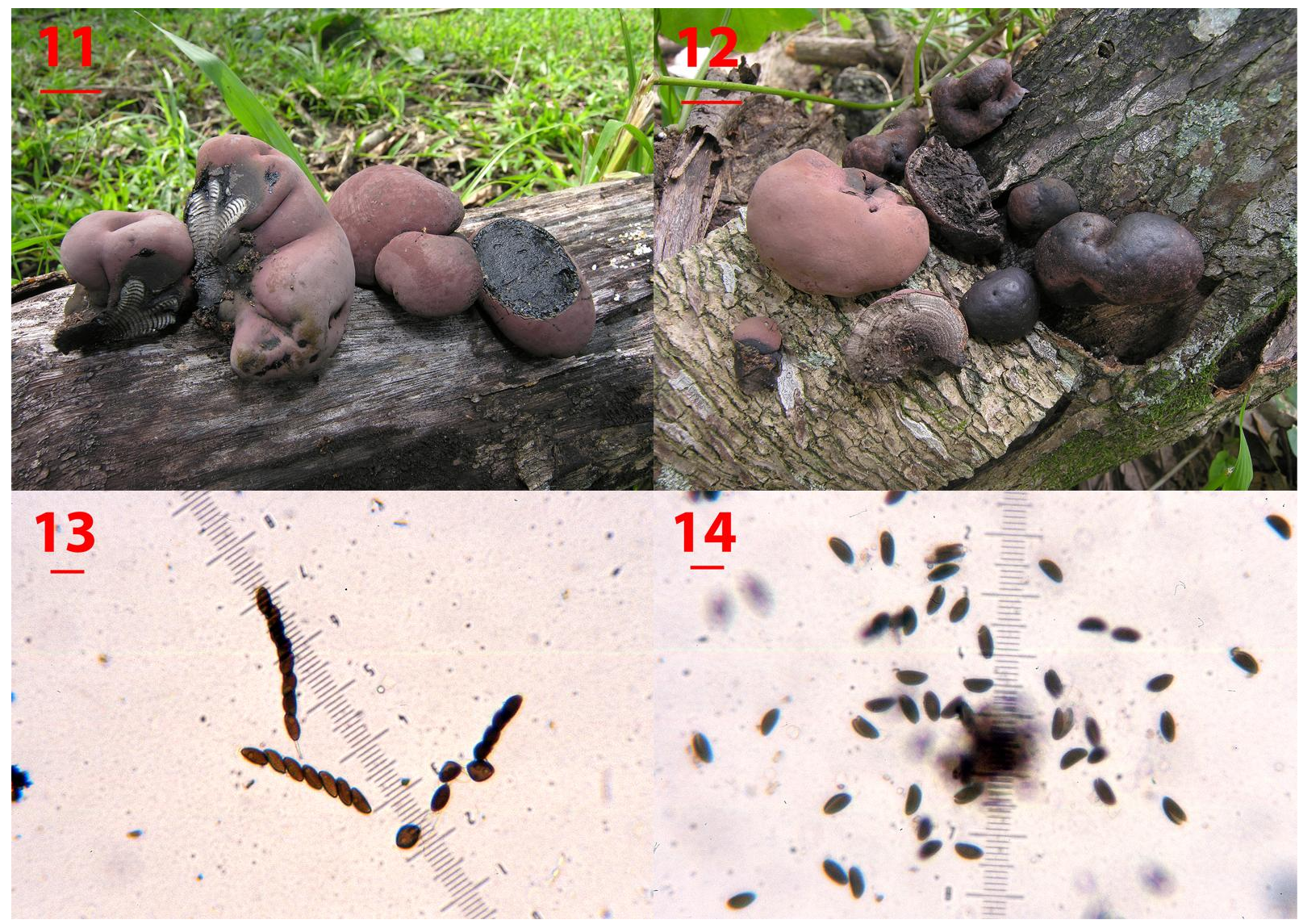

Figs 11-14 - Daldinia clavata. 11, 12 Apothecia in environment. 13, 14 Spores (mounted in water). Bars figs 11, $12=1.5 \mathrm{~cm}-$ fig $13=15 \mu \mathrm{m}-$ fig $14=10 \mu \mathrm{m}$.

noted is that on the same piece of host wood these two Cookeina are never simultaneously present. More information given in C. sulcipes.

Daldinia clavata Henn., Hedwigia 41: 14 (1902) Figs 11-15 = Daldinia argentinensis Speg., Anales Mus. Nac. Hist. Nat. Buenos Aires 8(1): 68 (1902) = Daldinia barbata Rick, Broteria 5: 50 (1906) = Daldinia argentinensis var. sessilis Speg., Anales Mus. Nac. Hist. Nat. Buenos Aires 19(12): 345 (1909)

= Daldinia concentrica f. clavata (Henn.) Theiss., Annls. Mycol. 7: 4 (1909)

= Daldinia albozonata Lloyd, Mycol. Writings 5: 822 (1919)

Ascocarp irregularly semi-globose, subclavate, turbinate, ob-pyriform, sessile to distinctly stalked; up to $50 \mathrm{~mm}$ wide and 30-40 $\mathrm{mm}$ high. Outer surface reddish fawn, vinousbrown, smooth or only minutely rough due to the low protrusion of the perithecia, tending to crack and expose the underneath blackish surface. In section the carpophore shows a cortical crown which houses the perithecia arranged in a single layer, supported by a zoned stroma made up by alternate whitish and grey-black bands approximately $0.5-1.5 \mathrm{~mm}$ high. Stalk, if visible, made up by the extension of the ascocarp, up to $25 \mathrm{~mm}$ long. Perithecia globose or globose-elongated, ob-ovoidal, some cylindrical, very slightly papillate, smooth, blackish, up to $1 \times 1 \mathrm{~mm}$. Consistency carbonaceous and somewhat fragile in all the fruit-body.

Ascospores (9-) 10-12 × 5-6(-8.5) mm, very irregular in shape, almost kidney-shaped to citriform, sub-elliptical, a few with one thinned extremity, often one side flattened, thick-walled (about $1 \mu \mathrm{m}$ ), without or 1-2 oildrops, showing one more or less convex or straight germinal slit not reaching the ends and sometimes enlarged up to $2 \mu \mathrm{m}$ near the centre, smooth, dark brown, uniseriate in the asci. Asci 80-90 × 8-10 $\mu \mathrm{m}$, club-shaped, showing a clearly visible and more or less disk-shaped 

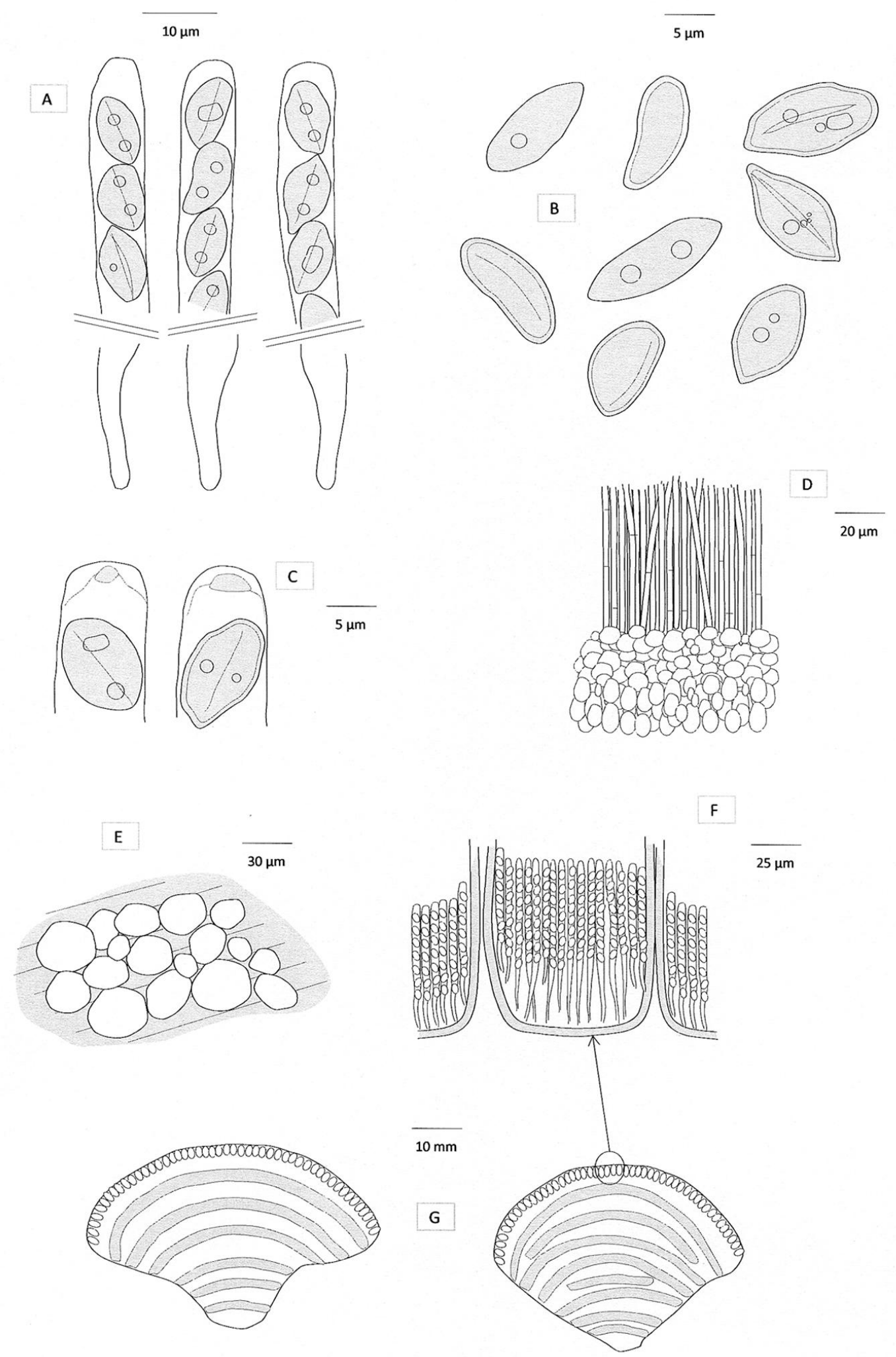

Fig. 15 - Daldinia clavata. A Asci with ascospores. B Released ascospores. C Asci (details of the apical apparatus). D Structure of the stroma. E Structure of the cortical tissue. F Perithecia (details). G Ascocarps in vertical section. 


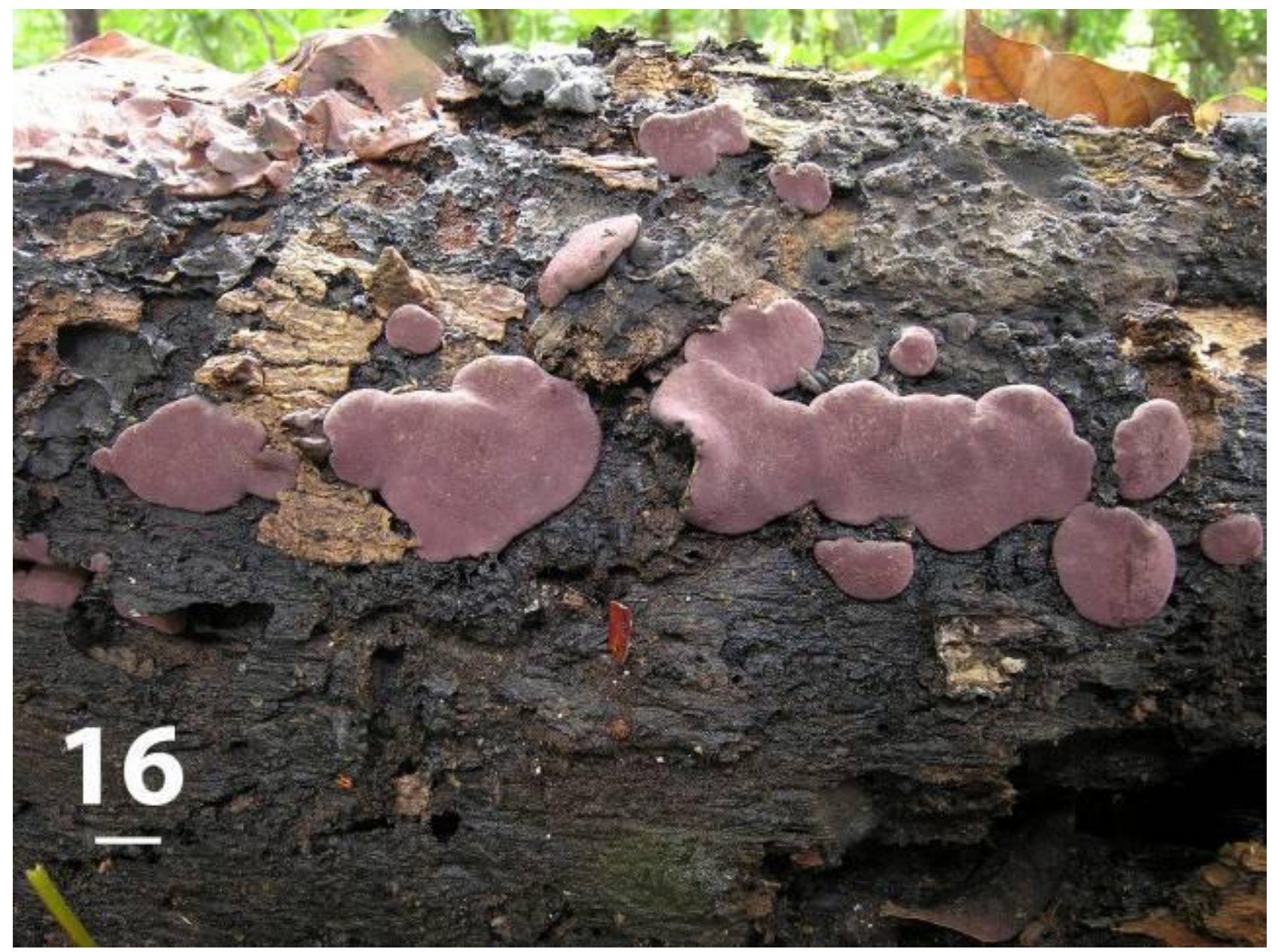

Fig. 16 - Hypoxylon anthochroum. Ascocarps in environment. Bar =1,5 cm.

apical apparatus, amyloid, 8-spored. Paraphyses absent. Cortical tissue of textura angularis, cells polygonal, up to $30 \mu \mathrm{m}$ diam., dark brown, immersed in a sort of finely granular, blackish matter. Stroma of indefinite textura, made up by bundles of parallel, septate hyphae $8-12(-15) \mathrm{mm}$ wide, some of them thick-walled, mixed with portions of textura globulosa-angularis, with globose or slightly elongated cells (some of them polygonal), pale to dark brown, 10-12 $\mu \mathrm{m}$ diam.

Habitat - in groups of more or less close fruit-bodies, on decaying wood of frondose tropical / equatorial trees, during the year.

Specimens examined - Dominican Republic, Rio S. Juan, 5 specimens on decaying tropical wood of deciduous trees, 23 Dec 2010, C. Angelini, JBSD 121943; Dominican Republic, Sosua, P.to Plata, 4 specimens on degraded wood of tropical deciduous trees, 8 Aug 2011,
C. Angelini; Dominican Republic, Santo Domingo, Jardin Botanico, 4 specimens on degraded wood of tropical deciduous trees, 2 Nov 2011, C. Angelini. Exsiccata in personal herbarium of one of the authors (C.A.) before being deposited in JBSD.

\section{Discussion}

D. clavata belongs to a rather complex group of fungi sometimes distinct only on the basis of some external features, whose identity is not always clear because of the difficulty of evaluation and quantification of these characters. The most similar species is $D$. cuprea Starbäck, divergent in the shorter or lacking stalk, showing a greater protrusion of the perithecia on the surface, with mouse-grey rather than dark purple (or missing) stromatic pigments treated with $\mathrm{KOH}$, and less degradable stroma; the other characters are almost identical, including the spore size [10- 
A $\frac{}{10 \mu \mathrm{m}}$

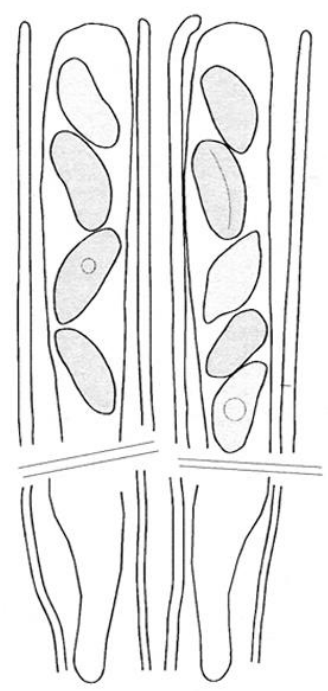

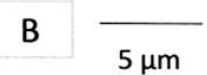
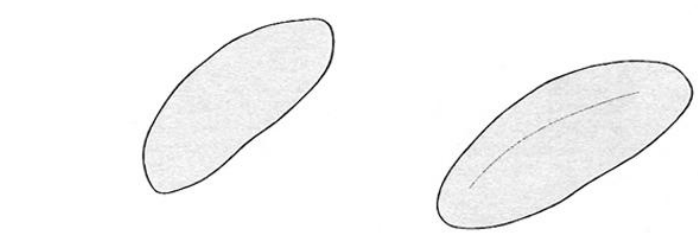

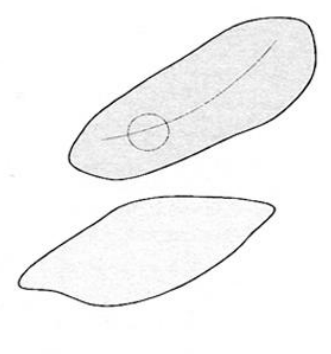

D

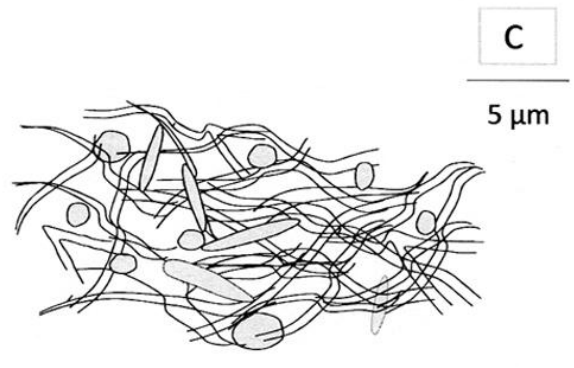

F
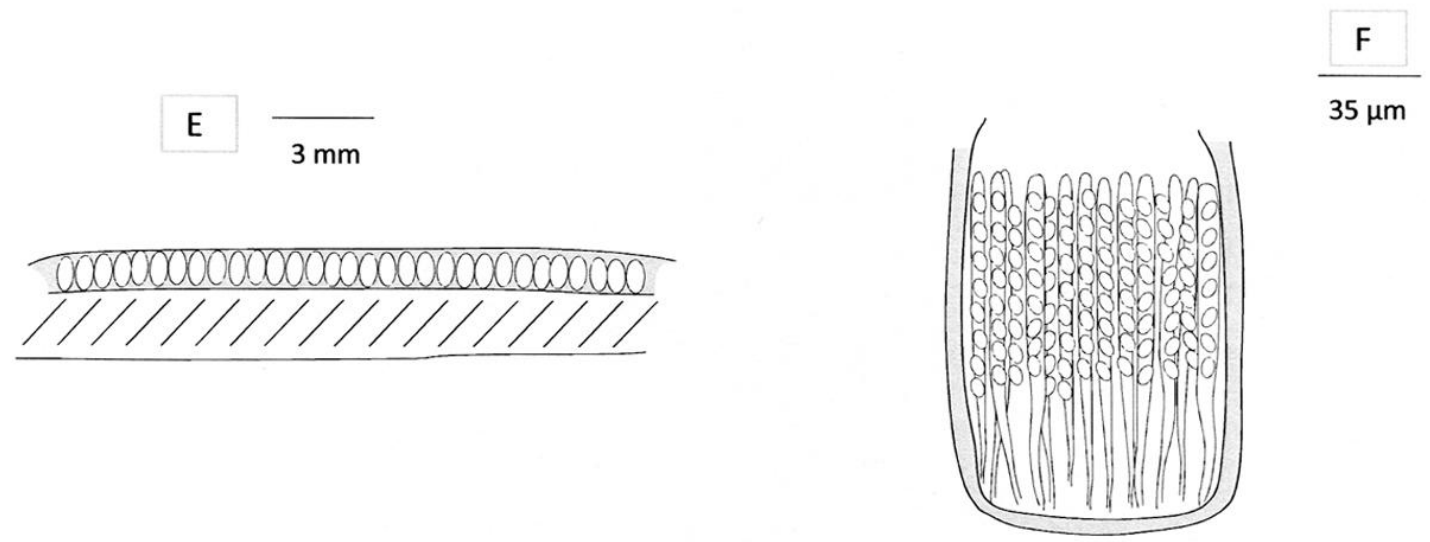

Fig. 17 - Hypoxylon anthochroum. A Asci with ascospores. B Released ascospores. C Structure of the stroma. D Structure of the cortical tissue. E Ascocarps in vertical section. F Perithecium (details).

$11.5 \times 4.5-5.5 \mu \mathrm{m}$, Ju et al. $1997 ; 10-12.5 \times 4-$ $4.5 \mu \mathrm{m}$, Dennis 1963]. Ju et al. (1997) analysed the holotype of these two entities and found a mixed situation, in terms of presence / absence of differentiating characters in both samples. Other Daldinia, with not strictly tropical / equatorial distribution share the general complexion and the colours of the ascocarps 
with D. clavata. Among them, D. eschscholzii (Ehrenb. : Fr.) Rehm, turbinate or pulvinate, sessile or with a short stout stalk, smooth, vinous-brown, vinous-grey or dark red-brick, up to grey-sepia, with stroma zoned by alternate dark brown and whitish bands, and on average larger ascospores, $10-14(-15.5) \times 5$ to $6.5 \mu \mathrm{m}$ (Ju et al. 1997); D. concentrica (Bolton : Fr.) Ces. \& De Not., globose-pyriform, pulvinate, sessile or subsessile, with rough surface due to the projection of the perithecia, vinous-brown to reddish-blackish, with stroma zoned by grey-brown and dark brown alternate strips, and larger ascospores, 12-15 x 6-7 $\mu \mathrm{m}$ (Medardi 2006); D. fissa Lloyd, turbinate, substalked, smooth, shiny, vinous-brown, with stroma zoned by whitish-grey bands significantly higher than the blackish ones, and ascospores 7-12 × 4.5-7 $\mu \mathrm{m}$ (Medardi 2006), $11,5-15,5 \times 6.5-9 \mu \mathrm{m}$ (Ju et al. 1997).

Hypoxylon anthochroum Berk. \& Broome, J. Linn. Soc. Bot. 14: 122 (1873) [1875]

Figs 16-17

= Hypoxylon murcidum Berk. \& Broome, J. Linn. Soc. Bot. 14(74): 123 (1873) [1875]

= Hypoxylon albostigmatosum Speg., Anal. Soc. Cient. Argent. 18(6): 271 (1884)

= Hypoxylon guarapiense Speg., Anal. Soc. Cient. Argent. 18(6): 272 (1884)

= Hypoxylon fuscopurpureum f. corticola Starbäck, Bih. K. Svenska VetenskAkad. Handl. 27(9): 9 (1901)

= Hypoxylon rubiginosum f. albostigmatosum (Speg.) Theiss., Annls Mycol. 7: 147 (1909)

Ascocarp as a crusty, effuse fruit-body, up to $10 \mathrm{~mm}$ thick and of variable extension; isolated fructifications can flow and join as they develop. Outer surface reddish tawny, reddish vinous, minutely wrinkled due to the low projection of perithecia. In section the carpophore shows a cortical crown containing the perithecia placed in a single layer, supported by a blackish-grey stroma. Perithecia more or less globose, slightly papillate, smooth, blackish, $0.5-0.8 \times 0.5-0.8 \mathrm{~mm}$. Consistency carbonaceous, but not brittle.

Ascospores 11-12 × 5-6 $\mu \mathrm{m}$ [8.5-13.5 $\times$ 4-6 $\mu \mathrm{m}$, San Martin et al. 1999a, b; Ju \& Rogers 1996], irregularly ellipsoidal, some one side flattened, other ones almost subfusiformangular, generally without guttule (only in rare cases 1 oil-drop), some of them showing a more or less convex or straight germinal slit not reaching the ends, smooth, more or less dark brown, uniseriate in the asci. Asci 110 $120 \times 6-7(-8) \mathrm{mm}$, club-shaped, amyloid, 8spored. Paraphyses cylindrical, thin, about 2 $\mu \mathrm{m}$ diam., with few septa. Cortical tissue of textura globulosa, cells rounded, 6-9 $\mu \mathrm{m}$ diam., dark brown, coated with a blackish, granular pigment. Stroma of non-traditional textura, made up by hyphae like vitreous "splinters", blackish, of very variable length, combined with blackish globules or granules also variable in size, all joined by portions of indefinite dark matter.

Habitat - in groups of more or less close fruit-bodies, on decaying wood of frondose tropical / equatorial trees, during the year.

Specimens examined - Dominican Republic, Rio S. Juan, 6 specimens on degraded tropical wood of deciduous trees, 3 Jan 2011, C. Angelini, JBSD 121942.

\section{Discussion}

Shape and colour of its fructification closely resemble those of $H$. rubiginosum (Pers. : Fr.) Fr., reddish brown with rusty tones, rough due to the projection of the perithecia, markedly thinner (only 1-2 mm), with widely overlapping ascospores, 10-11 $\times$ 5-6 $\mu \mathrm{m}$ (Medardi 2006) [(9-)10-12.5 × (4-)5-6 $\mu \mathrm{m}$, Dennis 1963; 9-12 × 4-6 $\mu \mathrm{m}$, Dennis 1981; 9$13 \times 4-7 \mu \mathrm{m}$, Ahti et al. 2000]. Of $H$. rubiginosum several varieties and forms were described, often elevated to specific rank, thus similar to $H$. anthochroum; among them, $H$. perforatum (Schwein. : Fr.) Fr. $[=H$. Rubiginosum var. perforatum (Schwein. : Fr.) L.E. Petrini], distinguishable only by the short stalked asci (Ahti et al. 2000), and $H$. cinnabarinum (Henn.) Y.M. Ju \& J.D. Rogers [= H. rubiginosum var. tropicum J.H. Mill.], with larger ascospores [12-17 × 5-7 $\mu \mathrm{m}$, Dennis 1963, as var. tropicum]. $H$. placentiforme Berk. \& M.A. Curtis is another very similar species with tropical / equatorial distribution; it differs in having a thinner basal 


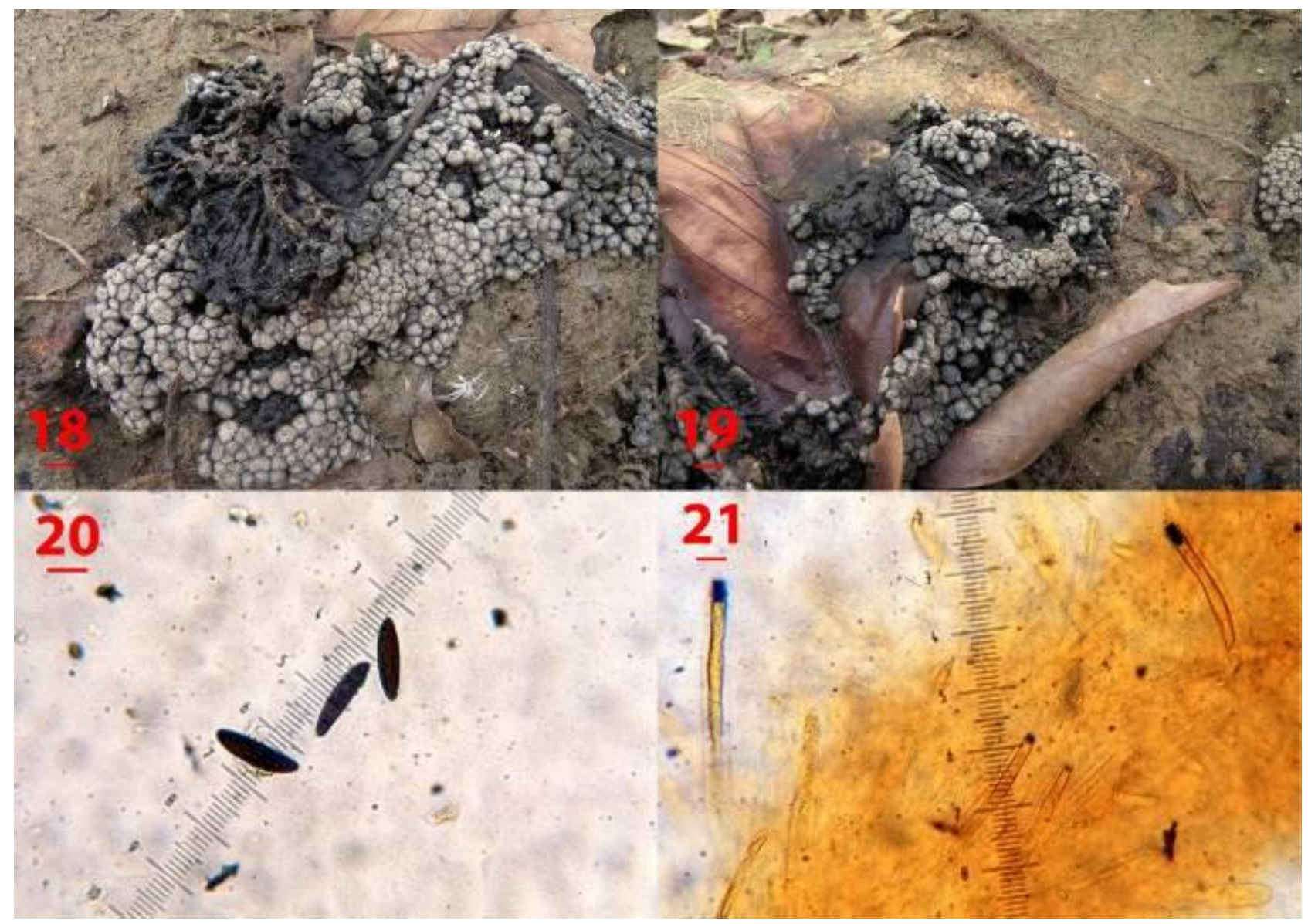

Figs 18-21 - Kretzschmaria cetrarioides. 18, 19 Ascocarps in environment. 20 Spores (mounted in water). 21 Asci (mounted in Melzer's reagent). Bars figs 18, $19=1 \mathrm{~cm}-$ figs 20, $21=15 \mu \mathrm{m}$.

stroma (1-9 $\mathrm{mm})$, more elongated perithecia, $0.3-0.6 \times(0.6-) 0.8-2 \mathrm{~mm}$ and larger ascospores, $8.5-18.5 \times 4.5-8(-8.5) \mu \mathrm{m}$, (Ju \& Rogers 1996).

Kretzschmaria cetrarioides (Welw. \& Curr.) Sacc., Syll. Fung. 2: 29 (1883) Figs 18-22 Basionym: Hypoxylon cetrarioides Welw. \& Curr., Trans. Linn. Soc. London 26: 282 (1867) $=$ Kretzschmaria lichenoides (Berk. \& Cooke) Sacc., Syll. Fung. 3: 29 (1883)

$\equiv$ Rhopalopsis cetrarioides (Welw. \& Curr.) Cooke, Grevillea 11: 94 (1883)

= Kretzschmaria proxima Pat., J. Bot., Paris 4: 63 (1890)

= Kretzschmaria pechuelii Henn., Bot. Jahrb. Syst. 14 (4): 365 (1891)

= Kretzschmaria paradoxa Pat., Bull. Soc. mycol. Fr. 8: 51 (1892)

= Kretzschmaria botrites Lloyd, Mycol. Writ. 6: 995 (1920)

$=$ Kretzschmaria singaporensis Sacc.,
Bollettino dell'orto Botanico della R. Università di Napoli 6: 48 (1921)

Ascocarps very extensive and covering a large surface of host wood, composed by several branched fruit-bodies, easily crumbling in blocks, consisting of numerous fasciculate stalked clavulae joined in the lower part, each one connected to the stalk by a sort of collar in relief. Clavulae single, 1-3 mm wide and 10$20 \mathrm{~mm}$ high, irregularly club-shaped, subcapitulate, compressed, seen from above with polygonal profile due to the mutual contact; apical part enlarged and sub-flattened or slightly convex, generally provided with a central rounded papilla. Upper surface more or less dark grey, sometimes grey-whitish, delicately cracking in areoles revealing the underneath grey-brown surface, black dotted due to the slight protrusion of the apical part of the perithecia, brownish on the papilla; lower surface darker, grey-blackish. In section, perithecia concentrically arranged on 1,2 or 3 
levels, immersed in a whitish stroma. Stalk (sterile) smooth, slightly gibbous, irregularly cylindrical-clavate, straight or sinuous, wider at the top near the collar, branched once or several times in the upper third (each extremity carrying a clavula), more rarely single, blackish. Several stalks converge at a single point of origin; below the clavulae, they resemble in shape a lichen of the genus Cetraria. Perithecia irregularly elongated, obpyriform or pear-shaped, smooth, blackish, 1$1.5 \times 1-1.5 \mathrm{~mm}$. Consistency carbonaceous and brittle.

Ascospores 35-36 × 7-8 (9) $\mu \mathrm{m}$ [26-34 $\times 8-11 \mu \mathrm{m}$, Dennis 1961], fusiform-curved, sickle-shaped, some almost navicular, also one side flattened, thick-walled (up to $1 \mu \mathrm{m}$ ), without guttulae to pluriguttulate, with a scantily visible germinal slit (more or less convex or slightly sinuous, in some cases straight, not reaching the ends), smooth, dark sooty-brown, irregularly uni-biseriate in the asci. Asci 100-110 × 9-10.5 $\mu \mathrm{m}$, cylindricalclavate, thick-walled $(2-2.5 \mu \mathrm{m})$, apical apparatus clearly visible and strongly amyloid, 8-spored. Paraphyses sharpen, irregularly thickened in some points, septate, hyaline, with some oil drops. Cortical tissue of textura intricata, hyphae more or less parallel, strongly tighten, 2-3 $\mu \mathrm{m}$ diam., septate, dark brown or blackish-brown. Stroma of textura intricata, hyphae irregular, septate, 5-7 $\mu \mathrm{m}$ in diam., but with several elements irregularly enlarged up to $20 \mu \mathrm{m}$, hyaline.

Habitat - in dense groups of close fruitbodies, on degraded wood of frondose tropical / equatorial trees, during the year.

Specimens examined - Dominican Republic, Rio S. Juan, several specimens on decaying tropical wood of deciduous trees, 23 Dec 2010, C. Angelini, JBSD 121919.

\section{Discussion}

The peculiar aspect of this fungus makes it easy to recognize in the field; its distinctive features are the confluence of several stalks (usually branched) in one point, and the way they extend below the clavulae that recalls a lichenoid development, together with the more or less polygonal shape, the presence of the central umbo and the grey colour of the clavulae. Dennis (1957, 1961) does not mention the collar we found joining the clavulae to the stalks.

The closest species is K. clavus (Fr. : Fr.) Sacc., also lignicolous and fruiting in the same environments, but it can be differentiated by the blackish rounded clavulae, up to $5 \mathrm{~mm}$ diam., flattened at the top and connected to individual or poorly branched short stalks joining in a single point of origin; its propagation below the clavulae is however much reduced, and it has larger ascospores, 28-38 × 7-10 $\mu \mathrm{m}$ (Dennis 1961). K. micropus (Fr. : Fr.) Sacc. also shows entirely grey-brown umbonate clavulae, composed of a single large perithecium with 1-5 ostiolar conical papillae, each one supported by a minutely hairy single stalk; it has smaller ascospores, indicatively 23 $\times 10 \mu \mathrm{m}$ [dimensions obtained from Dennis 1957: 310 (table), because not given in the text].

Some similarity in the appearance could be seen also with the fimicolous fungi of the genus Poronia Willd., whose clavulae are discshaped, top flattened and rounded, globose, whitish, generally supported by individual stalks; they produce considerably smaller ascospores, not curved and usually uniseriate in the asci.

Phillipsia crispata (Berk. \& M.A. Curtis) Le Gal, Bull. Jard. Bot. État 29: 103 (1959)

Figs 23-27

Basionym: Peziza crispata Berk. \& M.A. Curtis, in Berkeley, J. Linn. Soc. Bot. 10: 367 (1868) [1869]

$\equiv$ Lachnea crispata (Berk. \& M.A. Curtis) Sacc., Syll. Fung. 8: 169 (1889)

$\equiv$ Midotis crispata (Berk. \& M.A. Curtis) Cooke, Grevillea 21: 74 (1893) $\equiv$ Molliardiomyces crispatus Paden, Mycotaxon 25: 167 (1986)

Apothecia saucer-shaped to cup-shaped, turbinate, sometimes almost funnel-shaped, also flattened, sessile to stalked; up to $35 \mathrm{~mm}$ diam. and high. Hymenial surface smooth, more or less deep brown with some reddish-purple shades. Outer surface rough or granulose, with some weak furrows, whitish or pale brownish- 

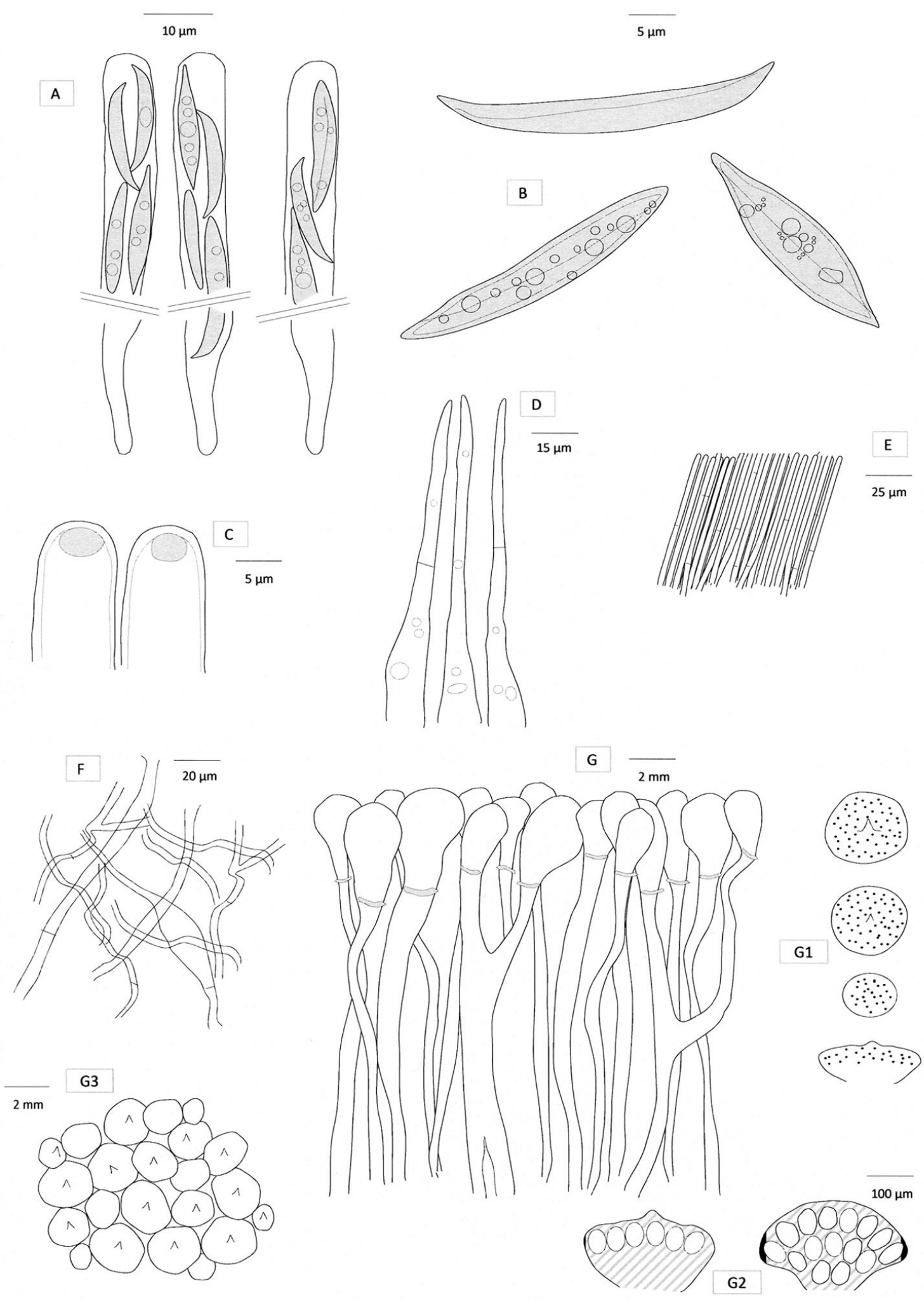

Fig. 22 - Kretzschmaria cetrarioides. A Asci with ascospores. B Released ascospores. C Asci (details of the apical apparatus). D Paraphyses. E Structure of the cortical tissue. F Structure of the stroma. G Fructification (G1 clavulae seen from above and in front); G2: vertical section of the upper part of two clavulae; G3: comprehensive fructification seen from above. 


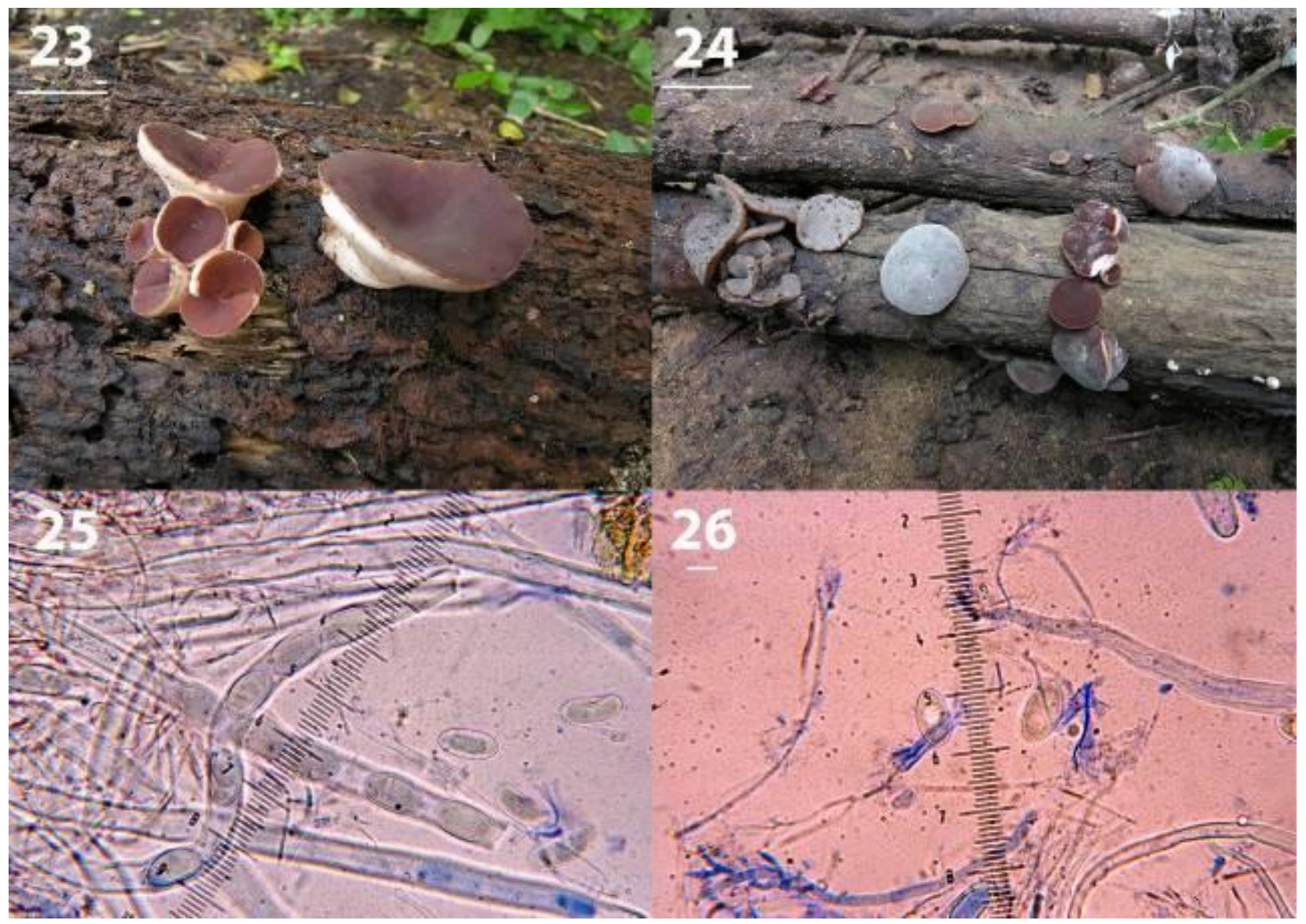

Figs 23-26 - Phillipsia crispata. 23, 24 Ascocarps in environment. 25, 26 Spores (coloured with lactic blue). Bars fig $23=1.5 \mathrm{~cm}-$ fig $24=3 \mathrm{~cm}$. - fig $25=20 \mu \mathrm{m}-$ fig $26=18 \mu \mathrm{m}$.

white; margin smooth, whole. Stalk (if present) comparable to a tapered extension of the fruitbody towards the bottom, widened at the top, with the same characteristics of the external surface. Flesh waxy but rather elastic, thick, whitish.

Ascospores 26-31 (32) $\times 12-15 \mu \mathrm{m}$ [22-33 × 11-15 $\mu \mathrm{m}$, Le Gal 1953; 22.4-24.8 × 10.4-13.6 $\mu \mathrm{m}$, Hansen et al. 1999; 25-28 $\times$ 14-16 $\mu \mathrm{m}$, Calonge et al. 2006b], irregularly kidney-shaped, asymmetric, some subfusiform, few regular in shape, generally with rounded ends, not many pointed, showing 1520 convex or rectilinear and more or less parallel longitudinal striations [9-12, Le Gal 1953; 15-18, Hansen et al. 1999; 10-20, Calonge et al. 2006b], hyaline, biguttulate, uniseriate in the asci. Asci 380-425 × 14-16 $\mu \mathrm{m}$, cylindrical, thick-walled (about $1.5 \mu \mathrm{m}$ ), with rounded or flattened and slightly swollen apex, non-amyloid, sub-operculate, 8-spored. Paraphyses 2-2.5 $\mu \mathrm{m}$ diam., thread-shaped, cylindrical, simple, septate. Subhymenium not obvious. Medullar excipulum very variable in thickness; textura intricata, hyphae 2-3 $\mu \mathrm{m}$ diam., rather interwoven, septate; presence of brown-purple pigments. Ectal excipulum variable in thickness; textura globulosaprismatica, cells more or less rectangular (15$20 \times 5-6 \mu \mathrm{m})$ or sub-globose $(18-22 \mu \mathrm{m}$ diam.), mixed with scarce hyphae like those of the medullar excipulum, globose-elongated and more or less perpendicular to the hymenium near the edge, brownish.

Habitat - in groups of more or less close fruit-bodies on decaying wood of frondose tropical / equatorial trees, November to April.

Specimens examined - Dominican Republic, Sosua, P.to Plata, locality Castillo, 5 specimens on degraded wood of tropical deciduous trees, 11 Jan 2011, JBSD 121914; Dominican Republic, Hermanas Mirabal, Salcedo, locality La Jibara, 7 specimens on 

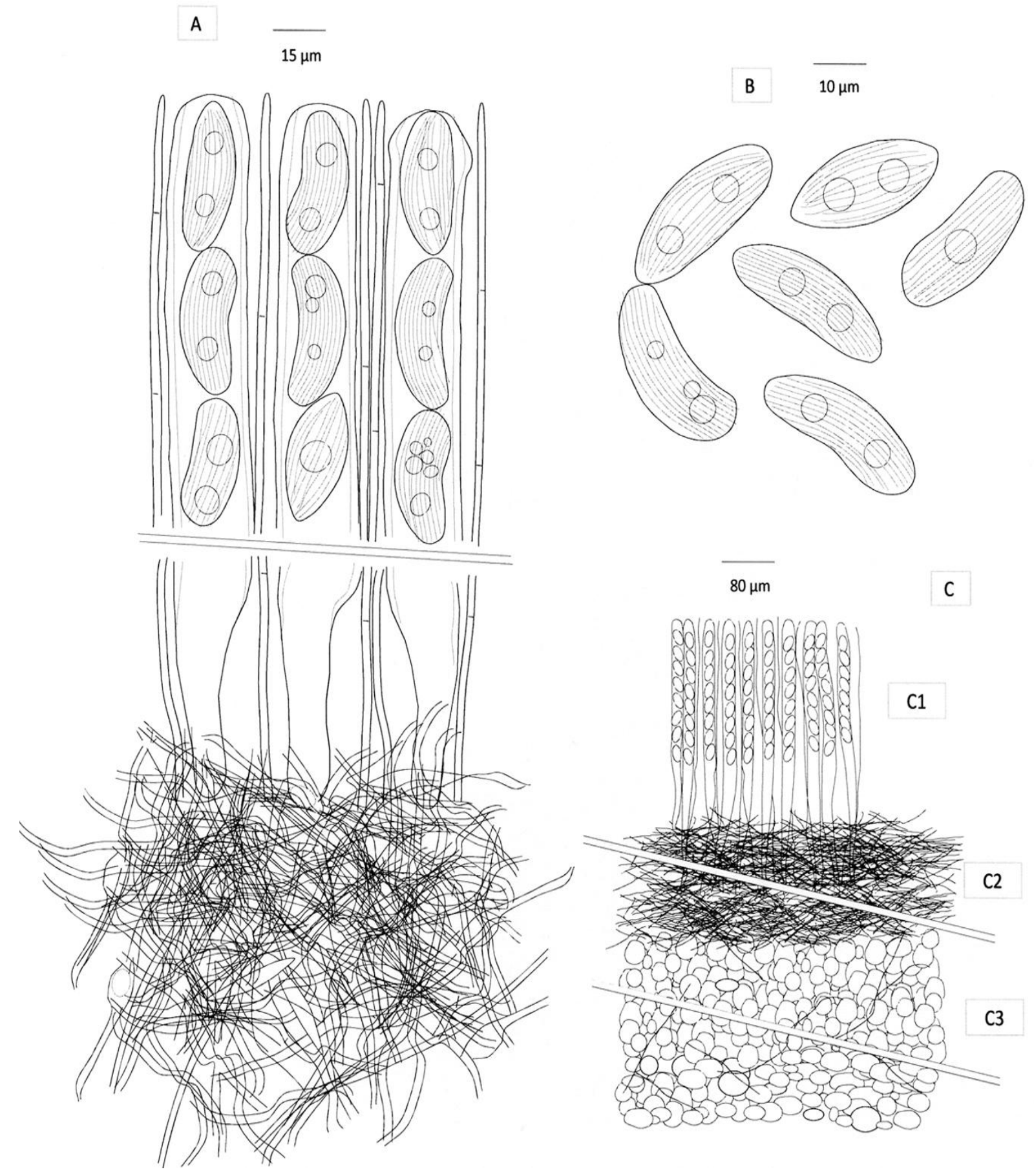

Fig 27 - Phillipsia crispata. A Asci with ascospores and a partial sight of the subhymenium. B Released ascospores. C Vertical section (C1 Hymenium - C2 medullar excipulum - C3 ectal excipulum).

degraded wood of tropical deciduous trees, 1 Dec 2011, C. Angelini; Dominican Republic, Sosua, P.to Plata, 3 specimens on degraded wood of tropical deciduous trees, 4 Dec 2011,
C. Angelini. Exsiccata in personal herbarium of one of the authors (C.A.) before being deposited in JBSD. 


\section{Discussion}

The genus Phillipsia Berk. consists of several lignicolous species widespread in the tropical / equatorial zone around the planet; the apothecia are more or less cartilaginous, with hymenial surface usually rather bright coloured although dark (as in the case of $P$. crispata) and contrasting with the very pale outer surface, whitish, yellowish, watery ochraceous or pink. Ascospores are usually asymmetric (kidney-shaped or sausage-shaped), less frequently regularly ellipsoidal or ellipsoidalfusiform, and show several more or less parallel, convex or almost straight longitudinal lines; in some cases they appear smooth or quite so under a conventional MSO, but actually more or less evidently wrinkled under SEM, at least at full maturity. The suboperculate asci allocate this genus in the family Sarcoscyphaceae Le Gal ex Eckblad.

The main characters of $P$. crispata are the colours of the hymenial surface and the ascospores, not because of their size (since they overlapped with those of other species), but for the 15-20 fine and dense longitudinal striations; in other similar species, if present, they do not exceed 15 in number, and thus are stronger and evident.

$P$. costaricensis Denison has cyathiform apothecia 5-23 mm diam., with ochraceousyellow-brown hymenial surface, paler outer surface, and shorter ascospores (17-25 × 12-15 $\mu \mathrm{m})$, with 7-12 incomplete longitudinal striations (Calonge et al. 2006b) [19.7-23.5 $\times$ 10.7-12 $\mu \mathrm{m}$, with 8-10 longitudinal striations, Zhuang 2003]. P. Dochmia (Berk. \& M.A. Curtis) Seaver has instead spoon-shaped apothecia up to $40 \mathrm{~mm}$ wide, sessile or subsessile, with yellowish or yellowish brown hymenial surface and paler outer surface; it forms ascospores $25-33 \times 12-15 \mu \mathrm{m}$ (Seaver 1928) [24-35 × 11-16 $\mu \mathrm{m}$, Le Gal 1953], with 4-6 longitudinal striations.

Other Phillipsia have lighter colours; $P$. lutea Denison has apothecia slightly cupshaped and sessile or subsessile, up to $30 \mathrm{~mm}$ diam., with lemon-yellow hymenial surface, whitish outer surface, and ascospores $30-40 \times$ 12-14 $\mu \mathrm{m}$ (Calonge et al. 2006b) [32.8-38 $\times$ 12.8-16 $\mu \mathrm{m}$, Hansen et al. 1999], with 5-6 longitudinal striations; $P$. crenulata (Sacc.) Le Gal has smaller apothecia (not more than 12 $\mathrm{mm}$ diam.) more or less uniformly pale orange and ascospores 16.5-23.5 × 9-13 $\mu \mathrm{m}$ (Le Gal 1953), but Moravec (1997), after analysis of the holotype, refers $15-19.5 \times 9.5-10.5 \mu \mathrm{m}$, with 6-7 longitudinal striations. $P$. crenulopsis W.Y. Zhuang also has small apothecia (3-12 mm diam.), disc-shaped, subsessile or substalked, hymenial surface orange or orange-red and paler outer surface; it has ascospores 16$20 \times$ 8.7-11 (12.5) $\mu \mathrm{m}$, showing 67longitudinal striations sometimes not entirely parallel, but irregular or branched (Zhuang 2003).

P. olivacea Rick has pulvinate-turbinate apothecia up to $40 \mathrm{~mm}$ diam. with more or less dark yellow-green-olive hymenial surface, sometimes with grey shades, whitish outer surface, and ascospores $25-31 \times 11-14 \mu \mathrm{m}$ (Calonge et al. 2006b) [(24-)26-29(-32.8) $\times$ (10.4-)12-12.2 (-14.4) $\mu \mathrm{m}$, Hansen et al. 1999], in this case not striate, but finely wrinkled.

A single case of entirely white apothecia is represented by P. ranomafanensis J. Moravec, sessile to stalked, up to $30 \mathrm{~mm}$ diam., with ascospores $15-19.5(-21) \times(7.5-)$ 9-10(-10.7) $\mu \mathrm{m}$ showing 7-10 parallel or anastomosed striations. Finally, a rather large group of Phillipsia has apothecia with more or less rose-red cyclamen hymenial surface, the best known species is maybe P. domingensis Berk.; see below for a description of this species.

Phillipsia domingensis Berk., J. Linn. Soc. Bot. 18: 388 (1881) Figs 28-32

Basionym: Peziza domingensis Berk., Ann. Mag. Nat. Hist. 9: 201 (1852)

$\equiv$ Otidea domingensis (Berk.) Sacc., Syll. Fung. 8: 97 (1889)

$\equiv$ Molliardiomyces domingensis Paden, Can. J. Bot. 62: 214 (1984)

Apothecia cup-shaped to disc-shaped, turbinate, subsessile or more or less evidently stalked; up to $60 \mathrm{~mm}$ diam. and high. Hymenial surface smooth, more or less intense pink-red, light magenta, cyclamen coloured; outer surface of granular appearance, with 


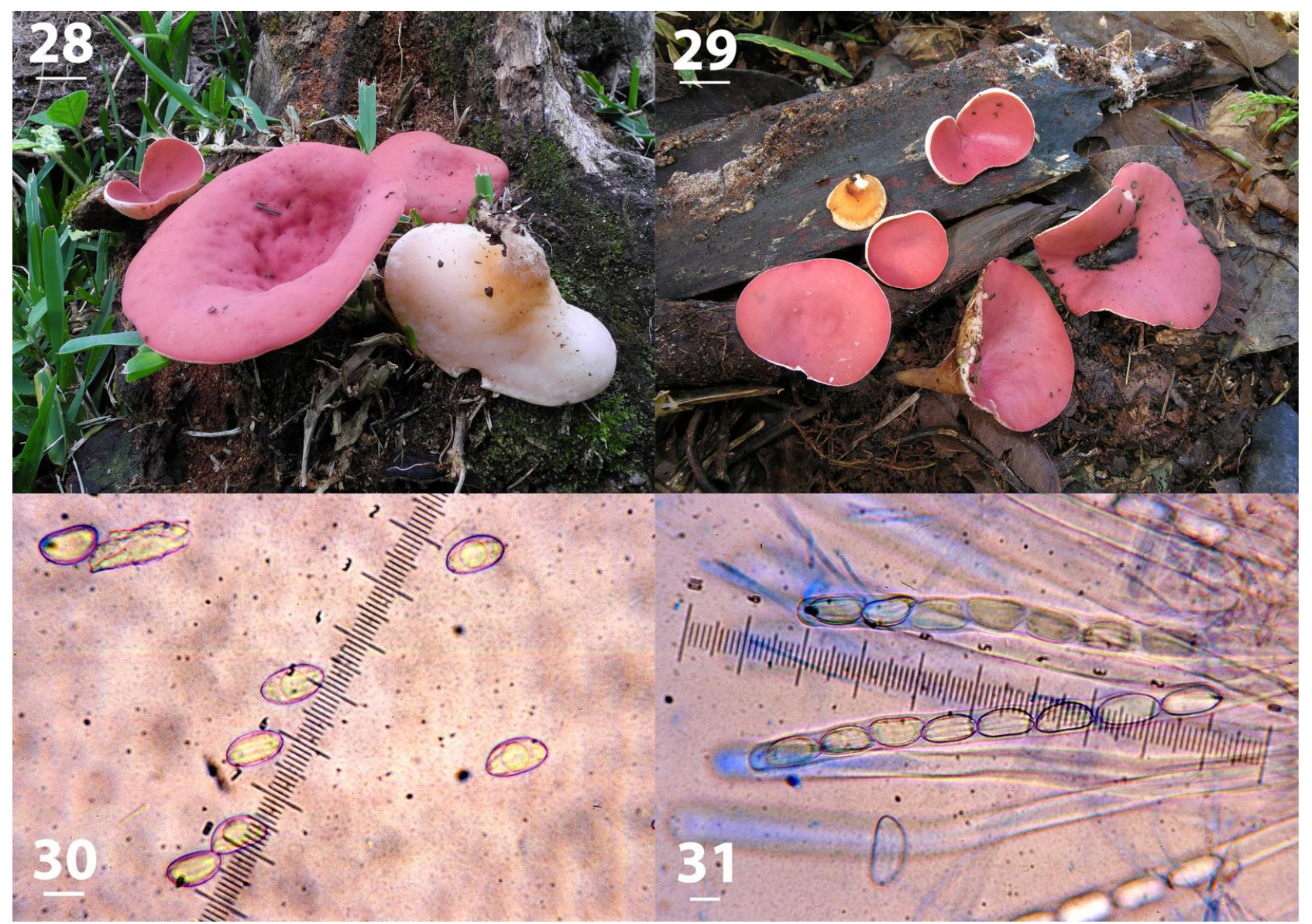

Figs 28-31 - Phillipsia domingensis. 28, 29 Apothecia in environment. 30 Spores in water. 31 Spores (coloured with lactic blue). Bars fig $28=1 \mathrm{~cm}-$ fig $29=1.5 \mathrm{~cm}-$ figs $30,31=16 \mu \mathrm{m}$.

more or less vertical strips or wrinkles, white or whitish, sometimes brownish-yellow spotted; margin regular, only slightly wavy, entire. Stalk tapered at the bottom and widened at the top where it connects to the apothecium, sometimes irregularly thickened in some points, with characteristics similar to the outer surface. Flesh tough and somewhat elastic, thick, whitish.

Ascospores $24-27 \times 11-13 \mu \mathrm{m}[25-30$ $\times 11-14 \mu \mathrm{m}$, Le Gal 1953; 21-27(-30) × 10.514(-15.5) $\mu \mathrm{m}$, Moravec 1997; 18-29 × 9-15 $\mu \mathrm{m}$, Hansen et al. $1999 ; 21.5-26.5(-30) \times$ 11.5-14(-15) $\mu \mathrm{m}$, Zhuang 2003; 20-30 × 14$18 \mu \mathrm{m}$, Calonge et al., 2006b], irregularly ellipsoidal-kidney shaped, some sub-fusiform or sub-citriform, asymmetrical, one side flattened, with (3-)4-6 slightly convex and more or less parallel obvious longitudinal striations, hyaline, mono-pluriguttulate, uniseriate in the asci. Asci 360-400 × 15-16(17) $\mu \mathrm{m}$, cylindrical, thick-walled (about $2 \mu \mathrm{m}$ ), unamyloid, sub-operculate, 8-spored. Presence of pink-reddish pigments in the lower part, visible especially in mass. Paraphyses 2-2.5 $\mu \mathrm{m}$ diam., thread-like, cylindrical or dilated up to $3 \mu \mathrm{m}$ at the top, simple, but in some cases also anastomosed, septate. Subhymenium not obvious. Medullar excipulum 500-600 $\mu \mathrm{m}$ thick, textura intricata, hyphae $2-3 \mu \mathrm{m}$ diam., interwoven, septate, mixed with globose hyphae about $10-15 \mu \mathrm{m}$ diam., more numerous towards the ectal excipulum. Ectal excipulum up to 1000 microns thick, as a continuation of the previous layer, but with more dense globose cells; near the margin there is a structure made up by hyphae parallel and perpendicular to the hymenium. Presence of granules of glassy appearance scattered throughout the section.

Habitat - in groups of close fruit-bodies on decaying wood of frondose tropical / equatorial trees, November to April.

Specimens examined - Dominican 

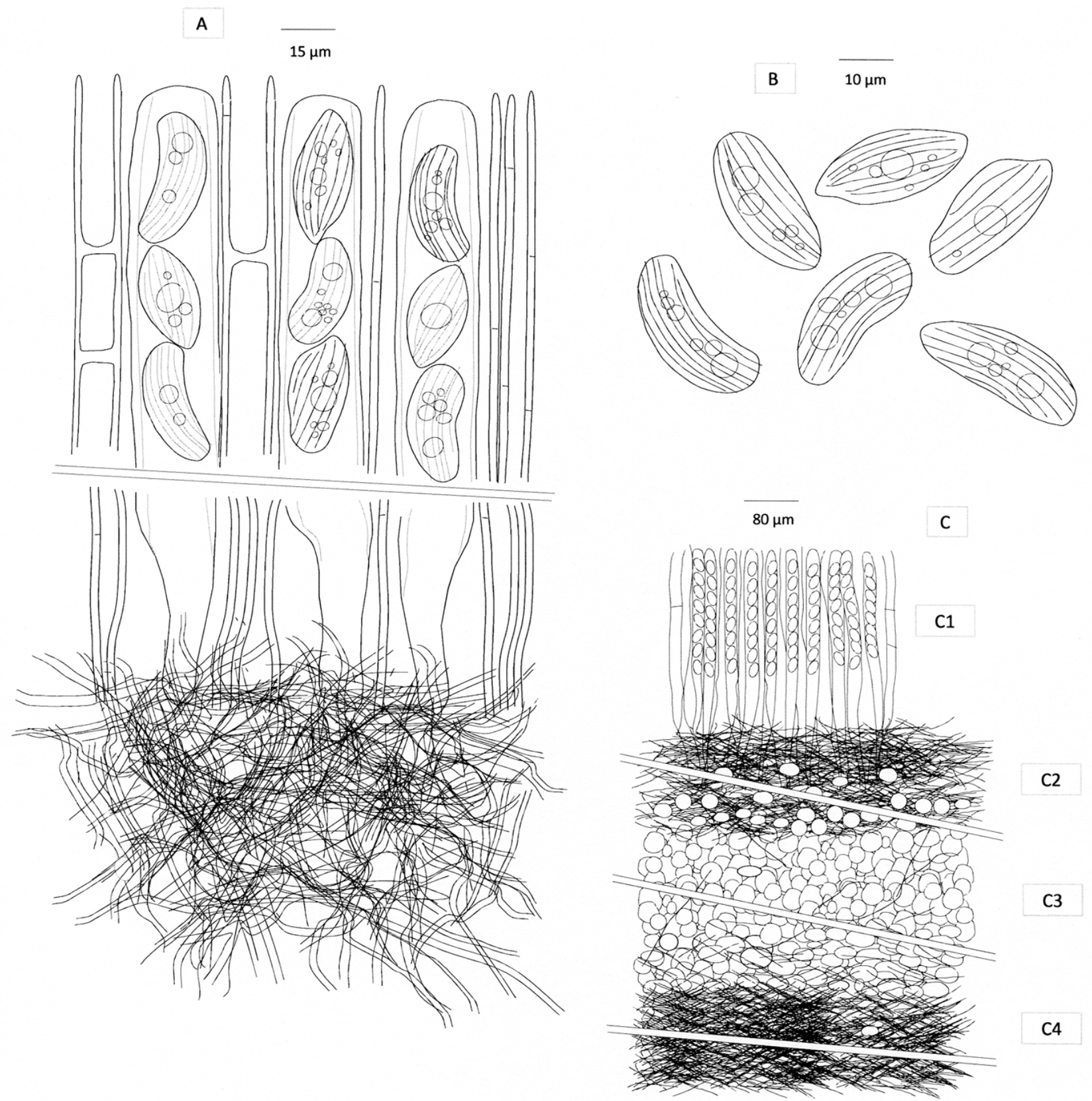

Fig. 32 - Phillipsia domingensis. A Asci with ascospores and a portion of the subhymenium. B Released ascospores. C Vertical section (C1 Hymenium. C2 Subhymenium. C3 Medullar excipulum. C4 Ectal excipulum).

Republic, Sosua, P.to Plata, 2 specimens on degraded wood of tropical deciduous trees, 11 Jan 2011, C. Angelini, JBSD 121911; Dominican Republic, Sosua, P.to Plata, 2 specimens on degraded wood of tropical deciduous trees, 8 Dec 2011, C. Angelini; Dominican Republic, La Vega, locality Jarabacoa, 6 specimens on degraded wood of tropical deciduous trees, 10 Dec 2011, C. Angelini. Exsiccata in personal herbarium of one of the authors (C.A.) before being deposited in JBSD.

\section{Discussion}

$P$. domingensis belongs to a group of fungi with more or less deep pinkish, red or red-purple hymenial surface that can be distinguished by the relatively large ascospores and their number of longitudinal striations. The main features of these fungi are summarized in Table 1. 
Table 1 Comparison among the main Phillipsia with pinkish, red or red-purple hymenial surface.

\begin{tabular}{|c|c|c|c|}
\hline Species & Apothecium & $\overline{\text { Ascospores }(\mu \mathrm{m})}$ & Spore ornamentation \\
\hline $\begin{array}{l}\text { P. carnicolor } \\
\text { Le Gal }\end{array}$ & $\begin{array}{l}\text { Up to } 10 \mathrm{~mm} \text { diam., spoon-shaped, } \\
\text { turbinate, sessile or subsessile. } \\
\text { Hymenial surface pale pink; outside } \\
\text { whitish }\end{array}$ & $\begin{array}{l}18.8-22.4 \times 10.4-12.8 \\
\text { (Hansen et al. 1999) } \\
17-20 \times 9.5-11 \quad(\text { Le Gal } \\
1953)\end{array}$ & $\begin{array}{l}\text { Smooth under MSO, with } \\
6-8 \quad \text { irregularly } \\
\text { anastomosed } r \text { striations } \\
\text { under SEM [7-10, Zhuang } \\
2003]\end{array}$ \\
\hline $\begin{array}{l}\text { P. chardoriana } \\
\text { Seaver }\end{array}$ & $\begin{array}{l}\text { Up to } 50 \mathrm{~mm} \text { diam., rounded, } \\
\text { subsessile. Hymenial surface brick-red, } \\
\text { bright red; outside paler }\end{array}$ & $26 \times 12($ Seaver 1928$)$ & $\begin{array}{l}\text { Longitudinal bands light } \\
\text { and dark }\end{array}$ \\
\hline $\begin{array}{l}\text { P. chinensis } \\
\text { W.Y. Zhuang }\end{array}$ & $\begin{array}{l}\text { Up to } 50 \mathrm{~mm} \text { diam., disc-shaped, } \\
\text { sessile or sub-stalked, less elastic than } \\
\text { in other species. Hymenial surface } \\
\text { purplish-red, sometimes with creamy } \\
\text { spots; outside yellow-pink or pink }\end{array}$ & $\begin{array}{l}(20.5-) 23-28(-30) \quad \times \\
(10.2-) 11-14 \quad \text { (Zhuang } \\
2003)\end{array}$ & $(7-) 8-11$ striations \\
\hline $\begin{array}{l}\text { P. domingensis } \\
\text { Berk. }\end{array}$ & $\begin{array}{l}\text { Up to } 40 \mathrm{~mm} \text { diam. and high, cup- } \\
\text { shaped to disc-shaped, turbinate, } \\
\text { subsessile o stalked. Hymenial surface } \\
\text { pink-red, pale magenta; outside whitish }\end{array}$ & $24-27 \times 11-13$ (our study) & $\begin{array}{l}(3-) 4-6 \quad \text { evident } \\
\text { longitudinal striations, } \\
\text { slightly convex and } \pm \\
\text { parallel }\end{array}$ \\
\hline $\begin{array}{l}P . \text { gigantea } \\
\text { Seaver }\end{array}$ & $\begin{array}{l}\text { Up to } 60 \mathrm{~mm} \text { diam. and } 40 \mathrm{~mm} \text { high, } \\
\text { funnel-shaped, grouped in number of } \\
3-4 \text { to the base. Hymenial surface } \\
\text { bright purple or red-purple; outside } \\
\text { whitish or rosy }\end{array}$ & $\begin{array}{l}25-27 \\
1928)\end{array} \times 12-14 \quad$ (Seaver & $\begin{array}{l}\text { Longitudinal bands light } \\
\text { and dark }\end{array}$ \\
\hline $\begin{array}{l}\text { P. hartmannii } \\
\text { (W. Phillips) } \\
\text { Rifai }\end{array}$ & $\begin{array}{l}\text { 2-10 mm diam., rounded, sessile or } \\
\text { subsessile. Hymenial surface pink; } \\
\text { outside whitish }\end{array}$ & $\begin{array}{l}16-18 \times 8-10 \\
(\text { Calonge et al. 2006b) }\end{array}$ & $\begin{array}{l}5-9 \quad \text { incomplete } \\
\text { longitudinal striations }\end{array}$ \\
\hline $\begin{array}{l}\text { P. kermesina } \\
\text { Kalchbr. \& } \\
\text { Cooke }\end{array}$ & $\begin{array}{l}\text { Up to } 16 \mathrm{~mm} \text { diam., disc-shaped or } \\
\text { spoon-shaped, sessile or subsessile. } \\
\text { Hymenial surface pale red-purple; } \\
\text { outside paler }\end{array}$ & $\begin{array}{l}25-35 \times 11-15 \text { (Le Gal } \\
1953)\end{array}$ & $\begin{array}{l}\text { Not present (ascospores } \\
\text { smooth) }\end{array}$ \\
\hline
\end{tabular}

$P$. carnicolor and $P$. hartmannii can be easily separated from $P$. domingensis by their smaller ascospores, while $P$. kermesina by its smooth ascospores. In the absence of more accurate data [Seaver (1928) did not detail the longitudinal stripes of the ascospores] and due to the overlapping of other characteristics, $P$. chardoriana can be separated by the red-brick hymenial surface and by the soft consistency, while $P$. gigantea for the tendency to show 3-4 apothecia grouped at the base. Finally, $P$. chinensis, as well as by shape and colour of the apothecia, can be distinguished by the large number of longitudinal striations of its ascospores.
Scutellinia cubensis (Berk. \& M.A. Curtis) Gamundí, Contr. Cient. Univ. Buenos Aires, Ser. Bot. 1 (2): 84 (1956) Figs 33-35 Basionym: Peziza cubensis Berk. \& M.A. Curtis, in Berkeley, J. Linn. Soc. Bot. 10: 366 (1868) [1869]

$\equiv$ Lachnea cubensis (Berk. \& M.A. Curtis) Sacc., Syll. Fung. 8: 176 (1889)

$\equiv$ Ciliaria cubensis (Berk. \& M.A. Curtis) Pat. Énum. Champ. Guadeloupe: 65 (1903)

$\equiv$ Humaria cubensis (Berk. \& M.A. Curtis) K.S. Thind \& Sethi, Indian Bot. Soc. 36: 202 (1957)

Apothecia slightly cup-shaped, especially in young specimens, then more 


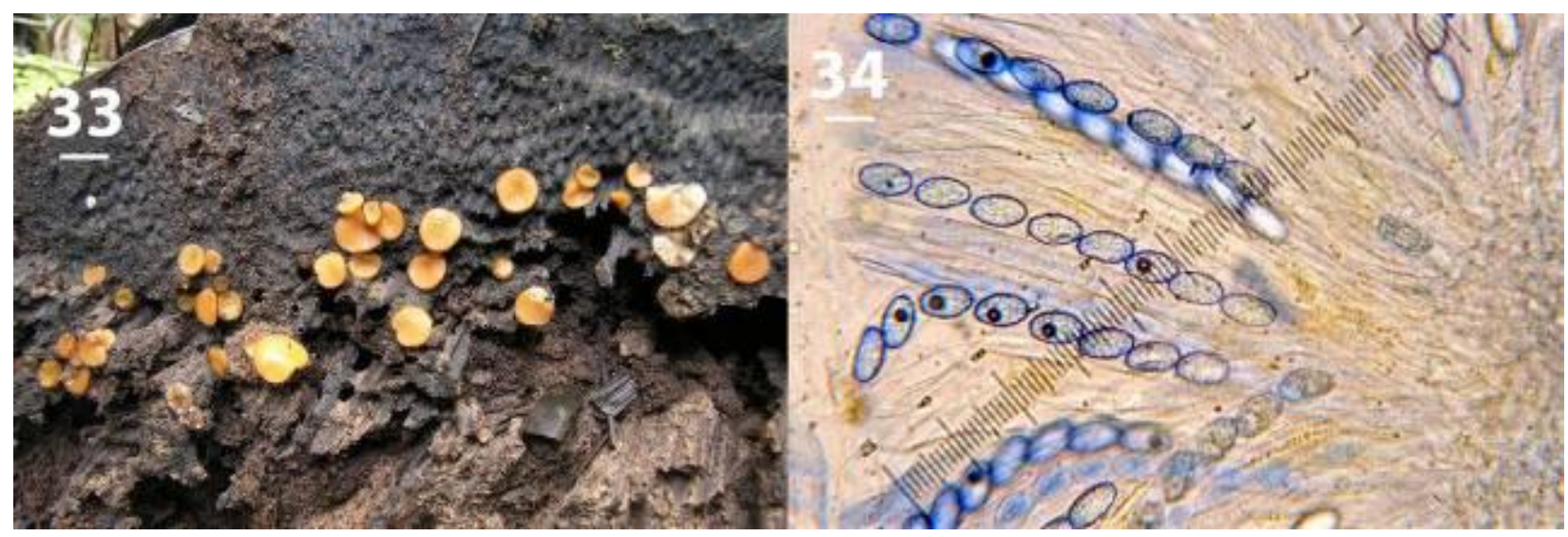

Figs 33-34 - Scutellinia cubensis. 33 Apothecia in environment. 34 Spores (coloured with lactic blue). Bars fig $33=1 \mathrm{~cm}-$ fig $34=15 \mu \mathrm{m}$.

opened, up to sub-flattened or disc-shaped, in some cases also reflexed, sessile; up to $10 \mathrm{~mm}$ diam. Hymenial surface smooth, more or less dull orange-red; outer surface concolorous, with dark brown hairs; margin smooth, whole, hairy. Flesh waxy and brittle, pale reddish.

Ascospores $15.5-18.5 \times 11.5-14.5 \mu \mathrm{m}$ [11.6-14.5 × 14.4-19 $\mu \mathrm{m}$, Gamundí 1956], broadly ellipsoid, with obvious warts irregularly elongated and joined (up to $3 \mu \mathrm{m}$ wide and up to $1.5 \mu \mathrm{m}$ high), hyaline, several oil drops, uniseriate in the asci. Asci 250-270 $\times$ 16-20 $\mu \mathrm{m}$, cylindrical, unamyloid, operculate, 8-spored. Paraphyses 2-2.5 $\mu \mathrm{m}$ diam., cylindrical, enlarged $7-8 \mu \mathrm{m}$ at the apex, simple or rarely forked, septate. Subhymenium scarcely notable, made up by a very thin inconstant layer of more or less globose cells, up to $10 \mu \mathrm{m}$ diam. Medullar excipulum about $200 \mu \mathrm{m}$ thick; textura intricata, hyphae 3-4 $\mu \mathrm{m}$ diam., interwoven, septate, hyaline. Ectal excipulum up to $350 \mu \mathrm{m}$ thick; textura globulosa-angularis, cells rounded-polygonal, up to $70 \mu \mathrm{m}$ diam. Marginal hairs up to 1100 $\mu \mathrm{m}$ long [1344 $\mu \mathrm{m}$, Gamundí 1956]; external hairs up to $400 \mu \mathrm{m}$ long, with simple or $2-3$ furcate base up to $35 \mu \mathrm{m}$ wide, stiff, septate, thick-walled (up to $6 \mu \mathrm{m}$ ), dark brown.

Habitat - in groups of more or less close fruit-bodies, on degraded wood of frondose tropical / equatorial trees, November to May.

Specimens examined - Dominican Republic, Sosua, P.to Plata, \pm 25 specimens on degraded wood of tropical deciduous trees, 11
Jan 2011, C. Angelini, JBSD 121915.

\section{Discussion}

The main characteristics of this Scutellinia are the relatively small ascospores and their distinct and connected irregular warts. Further lignicolous congeners distributed mainly in tropical and equatorial areas show similar appearances; the nature of the spore ornamentation is one differential character of great importance for their distinction, because the spore dimensions are often overlapping. Among them, S. colensoi Massee ex-Le Gal, showing ascospores $17.2-20.3 \times 9.8-11.6 \mu \mathrm{m}$ with amoeboid warts and hairs up to $2000 \mu \mathrm{m}$ long, with multifurcate base (Schumacher 1990) [ascospores $19-33 \times 11-19 \mu \mathrm{m}$ and hairs up to $2000 \mu \mathrm{m}$ long, Le Gal 1967; ascospores $18-20 \times 10-11 \mu \mathrm{m}$ and hairs up to $1200 \mu \mathrm{m}$ long, Kobayasi \& Otani 1971; ascospores 21.6-24(-27) $\times 11.5-14.4 \mu \mathrm{m}$ and hairs up to $1700 \mu \mathrm{m}$ long, Gamundí 1975; ascospores 18.5-23(-24.5) $\times 10.8-13.6(-14.2) \mu \mathrm{m}$ and hairs up to $1800 \mu \mathrm{m}$ long, Moravec 1978; ascospores (13.5-)15-20 × (7.5-)10-12 $\mu \mathrm{m}$, Douanla-Meli \& Langer,, 2005,)]; S. jungneri (Henn.) Clem. with ascospores 16.8-19.4 × $8.8-12.2 \mu \mathrm{m}$ with rounded or angular warts united in small plates and hairs up to $1200 \mu \mathrm{m}$ long, with 1-2 furcate base (Schumacher 1990); S. setosissima Le Gal, found also in continental areas [Croatia (Matočec et al. 1995)], with ascospores 17.8-23.5 × 9.8-13.2 $\mu \mathrm{m}$ decorated with fine warts joined into ridges and hairs up to $1250 \mu \mathrm{m}$ long with multifurcate 

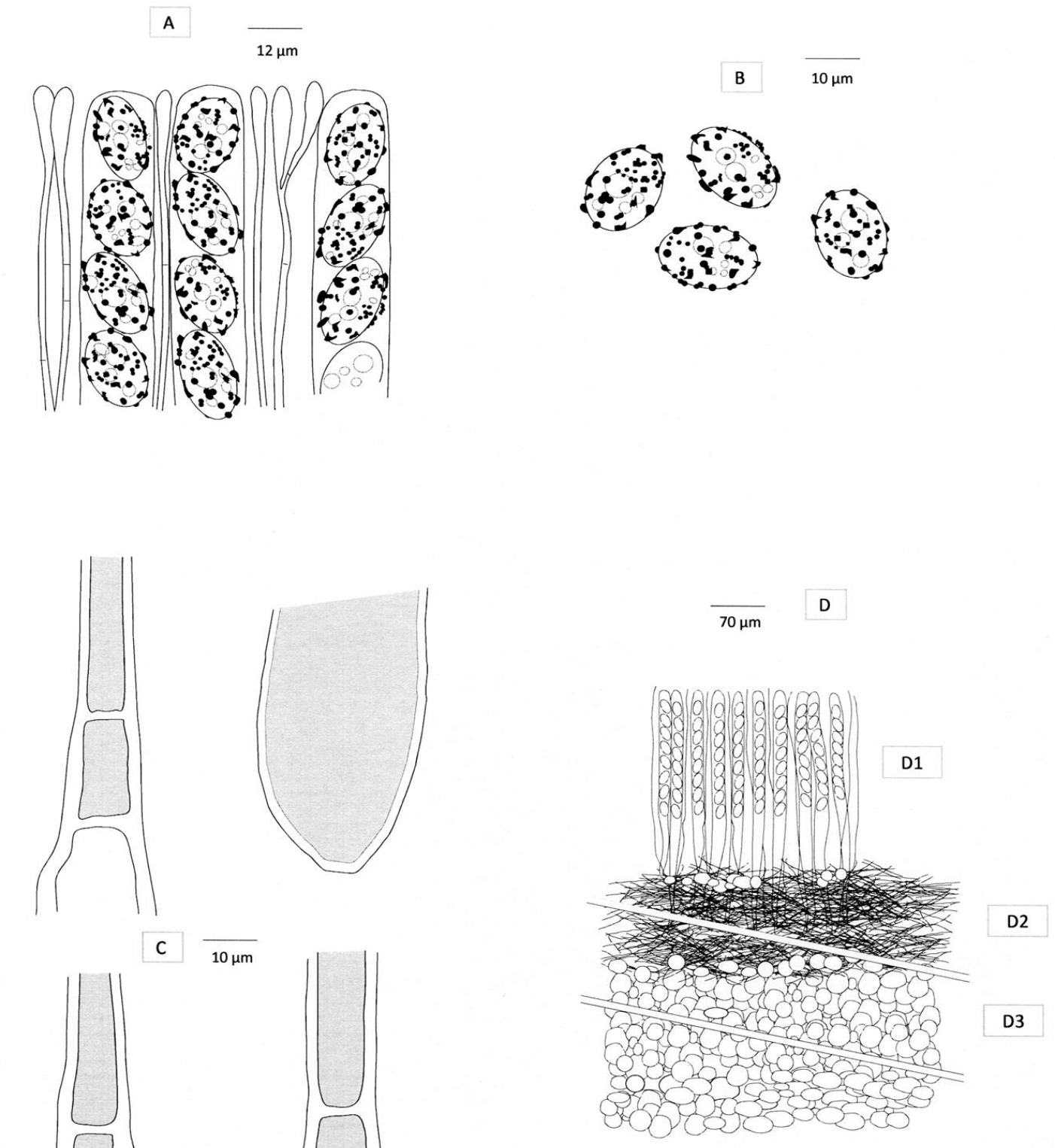

Fig. 35 - Scutellinia cubensis. A Asci with ascospores. B Released ascospores. C Hairs (lower part). D Vertical section (D1 Hymenium. D2 Medullar excipulum. D3 Ectal excipulum).

base, [ascospores 19-25 × 10-15 $\mu \mathrm{m}$ and hairs up to 2000 (2500) $\mu \mathrm{m}$ long, Le Gal 1969; ascospores $10.2-13.6 \times 17.1-21 \mu \mathrm{m}$ and hairs up to $1100 \mu \mathrm{m}$ long, Matočec et al. 1995; ascospores $20-22(-25) \times 10-15 \mu \mathrm{m}$ and hairs up to $1200 \mu \mathrm{m}$ long, Calonge et al. 2006a]. 


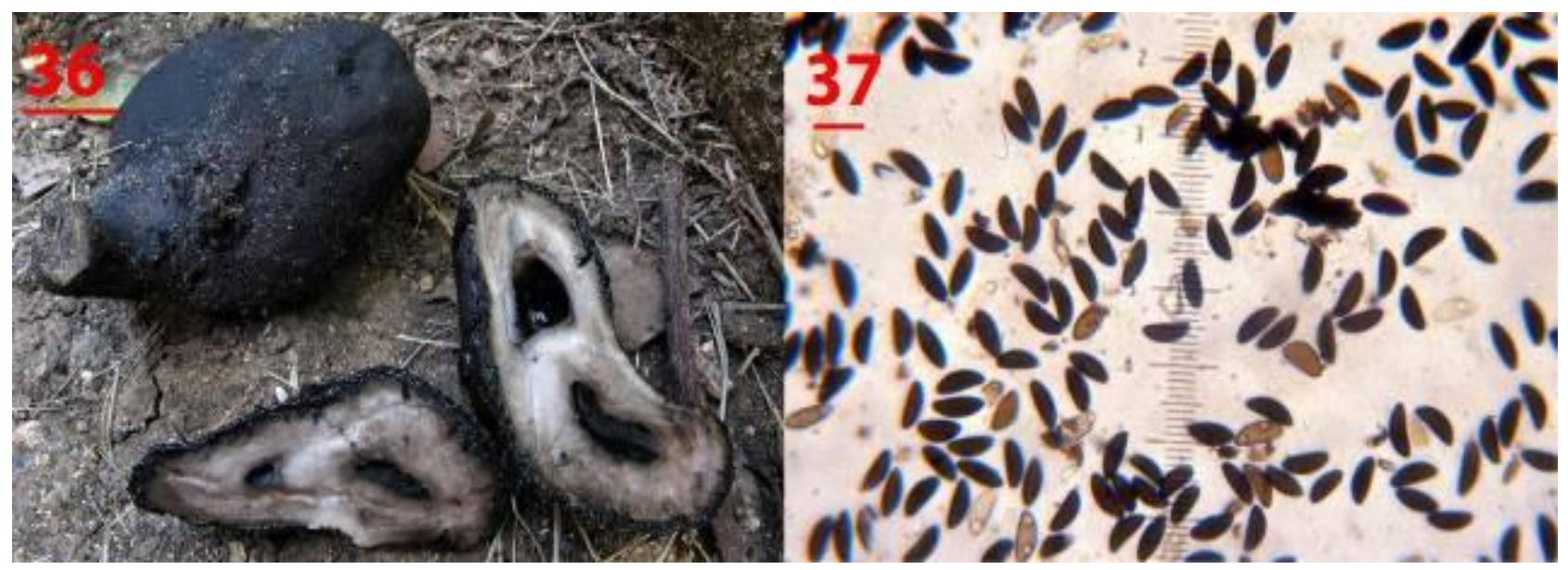

Figs 36-37 - Xylaria allantoidea. 36 Apothecia in environment. 37 Spores in water. - Bars fig $36=$ $2 \mathrm{~cm}-$ fig $37=15 \mu \mathrm{m}$.

Other species with the same distribution have larger ascospores and ornamentation often dissimilar. S. blumenaviensis (Henn.) Le Gal shows ascospores 12-16.8 $\times$ 21.2-28.8 $\mu \mathrm{m}$ with a hexagonal mesh pattern more evident at the poles and hairs up to $2000 \mu \mathrm{m}$ long with bimultifurcate base (Schumacher 1990); $S$. inexpectata Le Gal has ascospores 26.5-32.2 × $14.2-18 \mu \mathrm{m}$ showing rounded and isolated warts, and hairs up to $1200 \mu \mathrm{m}$ long with bimultifurcate base [ascospores 26.5-34 × 13$23.5 \mu \mathrm{m}$, Le Gal 1971; ascospores 26-30(-37) $\times 14-18(-23) \mu \mathrm{m}$ and hairs up to $1600 \mu \mathrm{m}$ long, Calonge et al. 2006a]; S. badio-berbis (Berk. ex Cooke) Kuntze has ascospores 18.2$23.2 \times 9.6-13.2 \mu \mathrm{m}$, with ridges and large anastomosed warts, and hairs up to $2000 \mu \mathrm{m}$ long having 2-3 furcate base (Schumacher 1990) [ascospores 19-24 × 9-14 $\mu \mathrm{m}$ and hairs up to $800 \mu \mathrm{m}$ long, Kobayasi \& Otani 1971; ascospores (18.3-)19.2-25 × (10-)11-14.4(15.7) $\mu \mathrm{m}$ and hairs up to $1500 \mu \mathrm{m}$ long, Gamundí 1975; ascospores 21.7- 23(-24.4) × 12.2-13.6(-15) $\mu \mathrm{m}$ and hairs up to $2000 \mu \mathrm{m}$ long, Moravec 1978]; S. balansae (Speg.) Gamundí has ascospores 18.2-24.8 × 12.2$14.8 \mu \mathrm{m}$ with irregularly amoeboid warts and hairs up to $2000 \mu \mathrm{m}$ long with 2-3 furcate base (Schumacher 1990) [ascospores 16-20 × 9$10.7 \mu \mathrm{m}$, Gamundí 1956; ascospores 13-17 × 8-11 $\mu \mathrm{m}$, hairs up to $470 \mu \mathrm{m}$ long, Pant \& Tewari 1974; ascospores 18.2-24.5 × 12.2$14.8 \mu \mathrm{m}$, Calonge et al. 2006a].

The rather remarkable variability of the spore size and length of the marginal hairs described in the literature leads us to assume that the species discussed above may still be insufficiently explored and/or retained as collective; the ambiguity, however, does not apply the basal conformation of the hairs and neither the spore ornamentation, common or largely overlapping in all the consulted texts.

Xylaria allantoidea (Berk.) Fr., Nova Acta R. Soc. Scient. Upsal., Ser. 3, 1: 127 (1851)

Figs 36-38

Basionym: Sphaeria allantoidea Berk., Ann. Mag. Nat. Hist., Ser. 1, 3: 397 (1839)

$\equiv$ Hypoxylon allantoideum (Berk.) Mont., Hist. Phys. Pol. Nat. Cuba Pl. Cell.: 350 (1842)

Ascocarp consisting of a subsessile clavula, $10-20 \mathrm{~mm}$ diam. (on the widest part) and up to $70 \mathrm{~mm}$ high. Clavulae single, ventricose to more or less regularly clubshaped, elongated, often curved. Surface black or blackish with faint reddish-purple reflections, rough due to the projection of the upper part of the perithecia, not cracked. In section they show the perithecia arranged in a single cortical layer, surrounded by a white or whitish stroma. In age the clavulae may become hollow. Stalk if appreciable (sterile), smooth, very short, tapered, widened at the top and concolorous to the clavula. Perithecia globose-papillate, slightly elongated, smooth, blackish, around $1 \times 0.8-1 \mathrm{~mm}$. Consistency carbonaceous and brittle in the cortical tissue, fibrous in the stroma. 

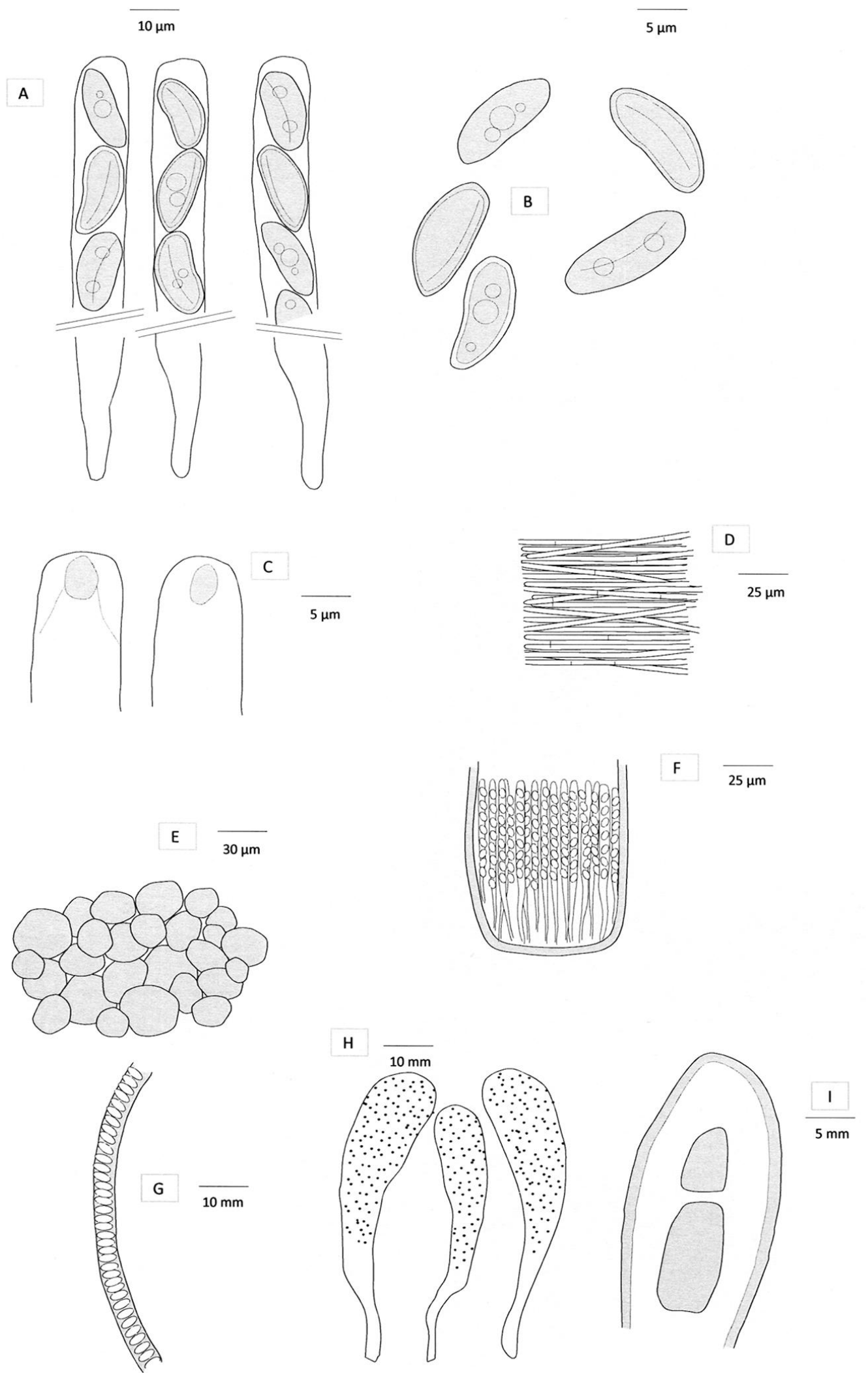

Fig. 38 - Xylaria allantoidea A Asci with ascospores. B Released ascospores. C Asci (details of the apical apparatus). D Structure of the stroma. E Structure of the cortical tissue. F Perithecium (details). G Cortical portion in section. H Clavulae. I Vertical section of one clavula. 
Ascospores (12.5-)15-16.5 × 3.55.5(-6) $\mu \mathrm{m}[11-16 \times 3.5-5 \mu \mathrm{m}$, Dennis 1956; ( 8.5-)10-12 × (3-)3.5-4.5 $\mu \mathrm{m}$, Rogers 1984, $1986 ; 12-14.5 \times 4-5 \mu \mathrm{m}$, Trierveiler-Pereira et al. 2009], irregularly fusiform-curved, one side flattened, thick-walled (up to $1 \mu \mathrm{m}$ ), with or without oil drops, equipped with a germinal slit more or less rectilinear which does not reach the ends, smooth, dark brown, uniseriate in the asci. Asci $100-115 \times 8.5-10 \mu \mathrm{m}$, cylindrical or cylindrical-club shaped, with evident apical apparatus, amyloid, 8-spored. Paraphyses absent. Cortical tissue of confused textura angularis, cells more or less polygonal, only rarely rounded, 10-15 $\mu \mathrm{m}$ diam., dark brown; presence of blackish granules of pigment. Stroma of textura intricata, hyphae thin, interwoven, septate, 2-3 $\mu \mathrm{m}$ diam., hyaline.

Habitat - in dense groups of close clavulae, on degraded wood of frondose tropical / equatorial trees, but also in continental areas, during the year.

Specimens examined - Dominican Republic, Sosua, P.to Plata, locality Castillo, 2 specimens on degraded wood of tropical deciduous trees, 19 Dec 2010, JBSD 121895.

\section{Discussion}

The main characters of this species are the shape of the clavulae (in age internally hollow) and the size of the ascospores. However, several other rather similar Xylaria are widespread on wood not only in equatorial and tropical zones, distinguishable on the basis of a detailed analysis.

$X$. aenea Mont. is the most similar species; it has club shaped-ellipsoidal clavulae, up to $70 \mathrm{~mm}$ high and $20 \mathrm{~mm}$ diam., with grey or reddish bronze furrowed surface, supported by a short stalk showing a small basal disc; it forms, however, considerably larger ascospores, 30-40 × 5-8 $\mu \mathrm{m}$ (Dennis 1956). $X$. guyanensis (Mont.) Fr. produces still higher clavulae (up to $100 \times 15 \mathrm{~mm}$ ), fusiform-club shaped, not distinctly stalked and with a broad base, with brown-blackish and rough surface; it forms larger ascospores, 14-21 $\times 5-8 \mu \mathrm{m}$ (Dennis 1956).

$X$. cubensis (Mont.) Fr. produces clavulae structurally similar, but smaller (up to
$40 \times 5-20 \mathrm{~mm}$, our study) $[40 \times 10 \mathrm{~mm}$ (Dennis, 1956)], whose surface is blackish grey with copper highlights, wrinkled or smooth, showing a small basal disc; it has, however, smaller ascospores, about 7-9 × 3-4 $\mu \mathrm{m}$ (our study) [7-9 × 3-4.5 $\mu \mathrm{m}$ (Dennis, 1956)].

The common and widespread $X$. polymorpha (Pers. : Fr.) Grev. shares the complexion with $X$. allantoidea; its clavulae are not infrequently grouped at the base, have rough blackish or blackish-grey surface and produce larger ascospores, 25-30 × 7-8 $\mu \mathrm{m}$ (Medardi 2006) [20-27(-30) × 6-9.5 (12) $\mu \mathrm{m}$, Dennis 1956; 20-32 × 5-9 $\mu \mathrm{m}$, Dennis 1981]. X. pallida Berk. \& Cooke forms instead thinner cylindrical or cylindrical-club shaped clavulae, up to $30 \mathrm{~mm}$ high and only $2.5 \mathrm{~mm}$ diam., abruptly tapered on the bottom in conjunction with the stalk, initially coated with a soft cream-coloured layer which cracks and leaves uncovered the blackish underlying surface; it has smaller ascospores, $10.5-12 \times 4.5-5 \mu \mathrm{m}$ (Dennis 1956).

With the same rather thin outline of $X$. pallida is also $X$. berkeleyi Mont., sometimes furcate at the base where a basal mycelium can be present, with blackish and finely reticulated surface and ascospores dimensionally similar to those of $X$. allantoidea, $11-16 \times 3.5-4.5 \mu \mathrm{m}$ (Dennis 1956). X. kegeliana (Lev.) Fr. produces stalked pointed-clavate clavulae, about $50 \times 5 \mathrm{~mm}$, with pale reddish and longitudinally fissured surface, blackish basal disc and considerably larger ascospores, 25-30 $\times 6-8.5 \mu \mathrm{m}$ (Dennis 1956); X. dealbata Berk. $\&$ M.A. Curtis has ellipsoidal or club-shaped clavulae up to $30 \times 10 \mathrm{~mm}$, blackish when completely mature, supported by a welldefined stalk, with ascospores larger, 24-33 $\times$ 6-11 $\mu \mathrm{m}$ (Dennis 1956). Also X. castorea Berk., reported from all continents, shares the external appearance with $X$. allantoidea, but its clavulae are rough and blackish with dark green highlights, have a clearly differentiated stalk and do not become hollow in age; it produces ascospores $11-13(-15) \times 5-6 \mu \mathrm{m}$ (Medardi 2006) [8-9 × 4-4.5 $\mu \mathrm{m}$, Ellis \& Everhart 1887; (8-)9-10(-11) × (3.5-)4.5-6 $\mu \mathrm{m}$, Rogers 1986; (8) 9.5-11 (14) × (4.5) 5.6 (6.5) $\mu \mathrm{m}$, Rogers \& Samuels 1986]. 

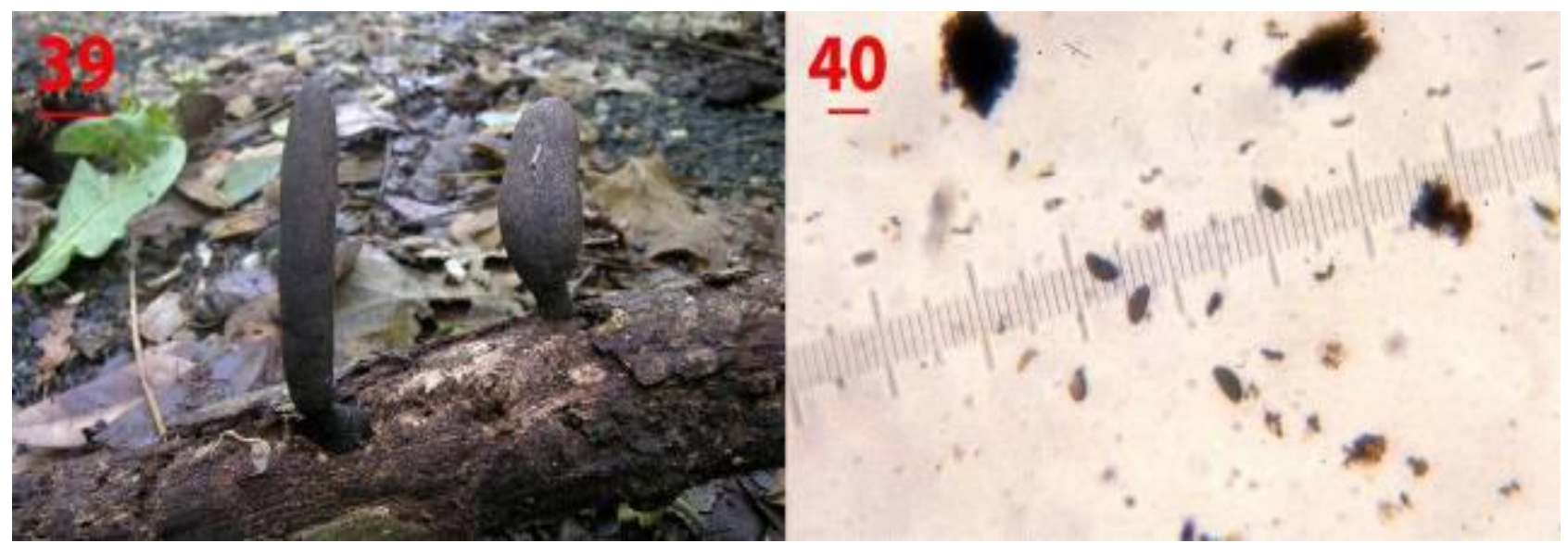

Figs 39-40 - Xylaria cubensis. 39 Apothecia in environment. 40 Spores in water. - Bars fig $39=1.2$ $\mathrm{cm}-$ fig $40=10 \mu \mathrm{m}$.

Xylaria cubensis (Mont.) Fr., Nova Acta R. Soc. Scient. Upsal., Ser. 3, 1: 126 (1851)

Figs 39-41

Basionym: Hypoxylon cubense Mont., Annls Sci. Nat. Bot., Ser. 2, 13: 345 (1840)

三Xylosphaera cubensis (Mont.) Dennis, Kew Bull. 13: 103 (1958)

= Xylosphaera papyrifera subsp. cubensis (Mont.) Dennis, Bull. Jard. Bot. État Brux. 31: 122 (1961)

= Xylaria papyrifera subsp. cubensis (Mont.)

D. Hawksw., Trans. Br. Mycol. Soc. 61: 200 (1973)

Ascocarp as a shortly stalked or subsessile clavula, 5-20 mm diam. and up to $40 \mathrm{~mm}$ high [(15) 30-70 (100) mm (Rogers 1984)]. Clavulae single, cylindrical or subventricose, thong-shaped (like a Geoglossum), sometimes also regularly clubshaped, elongated. Surface blackish-grey with copper highlights, rough by the projection of the upper part of the perithecia, minutely wrinkled, also curtly cracked in some points. In section, perithecia arranged in a single cortical layer, surrounded by a white or whitish stroma. In age the clavulae show some cavities. Stalk if present (sterile), smooth, rather short, tapered, concolorous, enlarged at the top and widened at the base in a sort of disk. Perithecia globoseelongate, slightly papillate, smooth, blackish, 0.5-0.8 $\times \quad 0.8-1 \quad \mathrm{~mm}$. Consistency carbonaceous and brittle in the cortical tissue, fibrous in the stroma.
Ascospores 7-9 × 3-4 $\mu \mathrm{m}$ [(7-)8$10.5(-13) \times(3.5-) 4-5(-6) \mu \mathrm{m}$, Rogers 1984 , 1986); $8-10 \times 4-5 \mu \mathrm{m}$, Rogers \& Samuels 1986; 4-5 × 8.5-11 $\mu \mathrm{m}$, Trierveiler-Pereira et al. 2009], ellipsoid-fusiform, often curved, one side flattened, 1 or more oil-drops, with a weak more or less straight germinal slit not reaching the ends and not always notable, smooth, dark brown, uniseriate in the asci. Asci 150-170 $\times$ 6-7.5 $\mu \mathrm{m}$, cylindrical, with a small but evident apical apparatus $(2-3 \mu \mathrm{m})$, amyloid, 8 -spored [also 4-spored, Carroll 1964].

Paraphyses absent. Cortical tissue of obscure granular textura (granules blackish, with toothed outline, concentrated in groups up to $15 \mu \mathrm{m}$ diam.) with some portion of textura globulosa-angularis (cells rounded or polygonal, up to $15 \mu \mathrm{m}$ diam., very dark brown). Stroma of textura intricata, hyphae thin, strongly interwoven, septate, 2-2.5 $\mu \mathrm{m}$ diam., hyaline.

Habitat - in groups on degraded wood of frondose tropical / equatorial trees, but also in continental areas, during the year.

Specimens examined - Dominican Republic, Sosua, P.to Plata, locality Castillo, 2 specimens on degraded wood of tropical deciduous trees, 19 Dec 2010, JBSD 121912.

\section{Discussion}

This species is closely related in shape and colours to $X$. allantoidea (Berk.) Fr., growing in the same environment but forming 


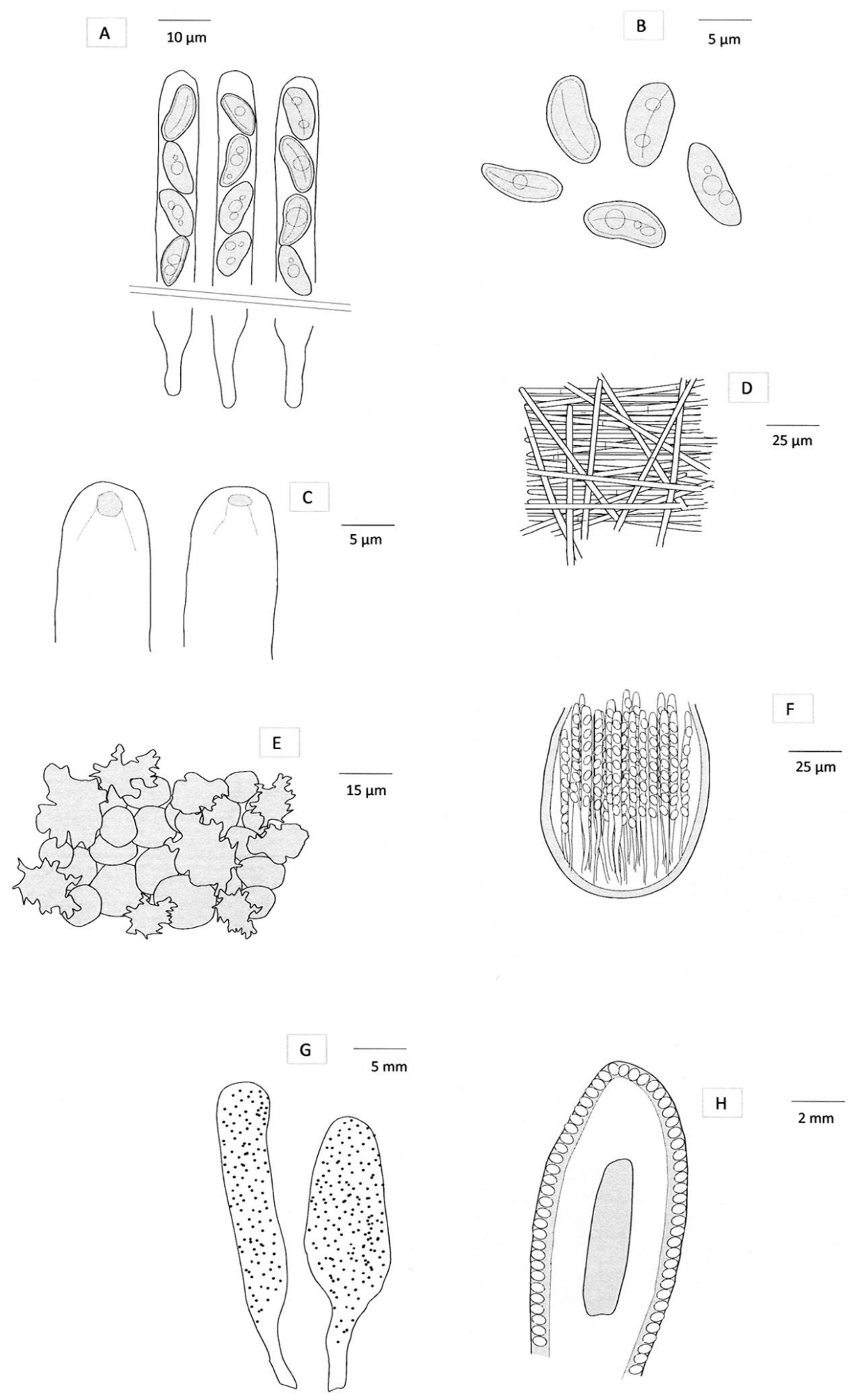

Fig. 41 - Xylaria cubensis. A Asci with ascospores. B Released ascospores. C Asci (details of the apical apparatus). D structure of the stroma. E Structure of the cortical tissue. F Perithecium (details). G Clavulae. H Vertical section of one clavula. 


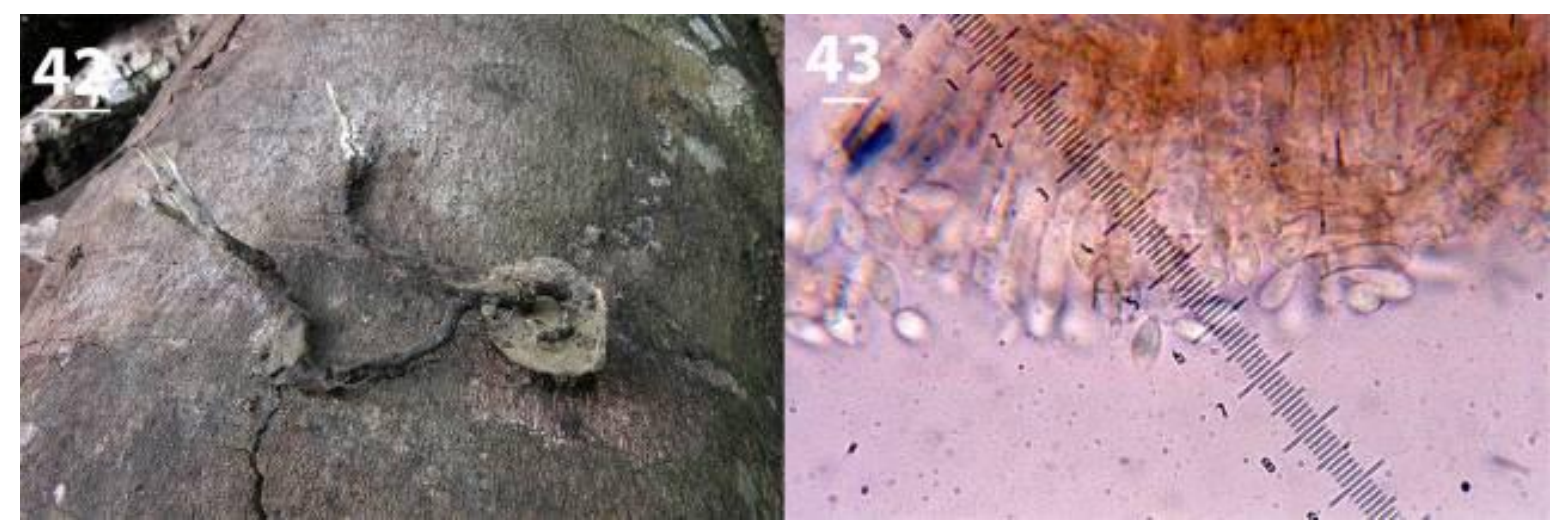

Figs 42-43 - Xylaria multiplex. 42 Apothecia in environment. 43 Conidia in water. - Bars fig $42=$ $3 \mathrm{~cm}-$ Fig $43=4.5 \mu \mathrm{m}$.

larger ascospores (12.5-)15-16.5 × 3.5-5.5(-6) $\mu \mathrm{m}$ (our study). The outline of the ascocarps is also reminiscent of $X$. longipes Nitschke, however, without reddish reflections and as well with larger ascospores $13-15 \times 6-7 \mu \mathrm{m})$ (Medardi 2006). Also X. curta Fr. has cylindrical-club shaped clavulae, single or grouped, but smaller (18 mm high), with blackish brown surface showing yellowish small scales; it has slightly longer ascospores, 8-11 $\times 3.5-5 \mu \mathrm{m}$, with a more evident germinal slit as long as the entire spore (Trierveiler-Pereira et al. 2009). X. guyanensis (Mont.) Fr. produces rather larger clavulae (up to $100 \times 15 \mathrm{~mm}$ ), fusiform-clavate, not stalked but enlarged near the base, blackish brown, rough, and larger ascospores, 14-21 × 5-8 $\mu \mathrm{m}$ (Dennis 1956).

Xylaria multiplex (Kunze in Fr. : Fr.) Fr., Nova Acta R. Soc. Scient. Upsal., Ser. 3, 1: 127 (1851)

Figs 42-44

Basionym: Sphaeria multiplex Kunze : Fr. in Fr., Linnaea 5: 536 (1830)

$\equiv$ Hypoxylon multiplex (Kunze in Fr. : Fr.) Mont., Ann. Sci. Nat. Bot. 13: 349 (1840) $\equiv$ Xylosphaera multiplex (Kunze in Fr. : Fr.) Dennis, Kew Bull. 13: 105 (1958)

Ascocarp (conidial stage) made up by a stalked and branched clavula, 60-180 mm high. Clavulae single, horn-shaped, arborescent, flexuous, with an irregularly cylindrical base, more or less compressed in some points, widening and branching in some sharp ends at the top, cylindrical or flattened too; the base is about $2 / 3$ of the total height.
Surface of the stalk portion smooth upward, but tomentose-hairy at the base, blackish with weak greenish tinges, longitudinally furrowed;it appears covered by a clayey crust, thin and easily removable, cracking and peeling in small plates. Surface of the upper third whitish, pruinous by coating of conidia; the tips of the terminations are pale orange and a few patches of the same colour can be found in other points. Stroma whitish-grey. Consistency carbonaceous and brittle in the crust covering the lower part of the fructification, fibrous in the stroma.

Conidia 5-6(-9) $\times$ 2.5-3 $\mu \mathrm{m}$, irregularly ellipsoidal, subfusiform, some of them club-shaped or cuneiform, other ones slightly curved, with or without guttulae. Conidial hyphae interwoven, hyaline, septate, about $3 \mu \mathrm{m}$ diam. Cortical tissue of textura intricata, sometimes parallel, hyphae dark brown, septate, $2.5-3 \mu \mathrm{m}$ diam., coating a layer of textura globulosa with dark cells of about 10 $\mu \mathrm{m}$ diam. Stroma of textura intricata-parallel, hyphae septate, also furcate, up to $3 \mu \mathrm{m}$ diam., hyaline or slightly brownish. Tomentum of the stalk consisting of hyphae variably long, 3-4 $\mu \mathrm{m}$ diam., brown, thick-walled, septate.

Habitat - in group of fasciculate or single individuals, on degraded wood of frondose deciduous trees in all the environments, tropical, equatorial or continental, during the year.

Specimens examined - Dominican Republic, Rio S. Juan, 2 specimens on decaying tropical wood of deciduous trees, 23 Dec 2010, C. Angelini, JBSD 121910. 

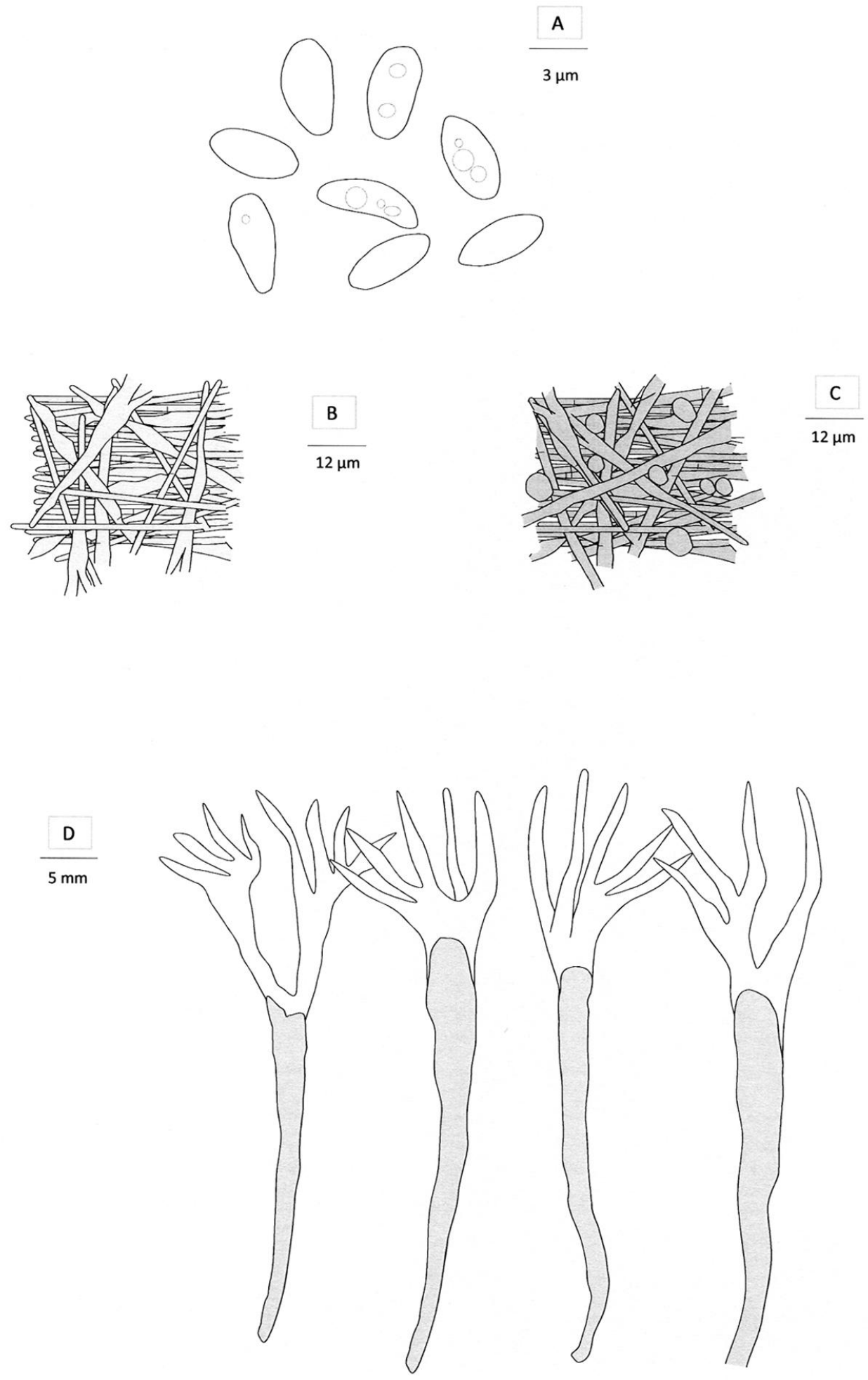

Fig. 44 - Xylaria multiplex. A Conidia. B Structure of the stroma. C Structure of the cortical tissue. D Fruit-bodies in the conidial stage. 


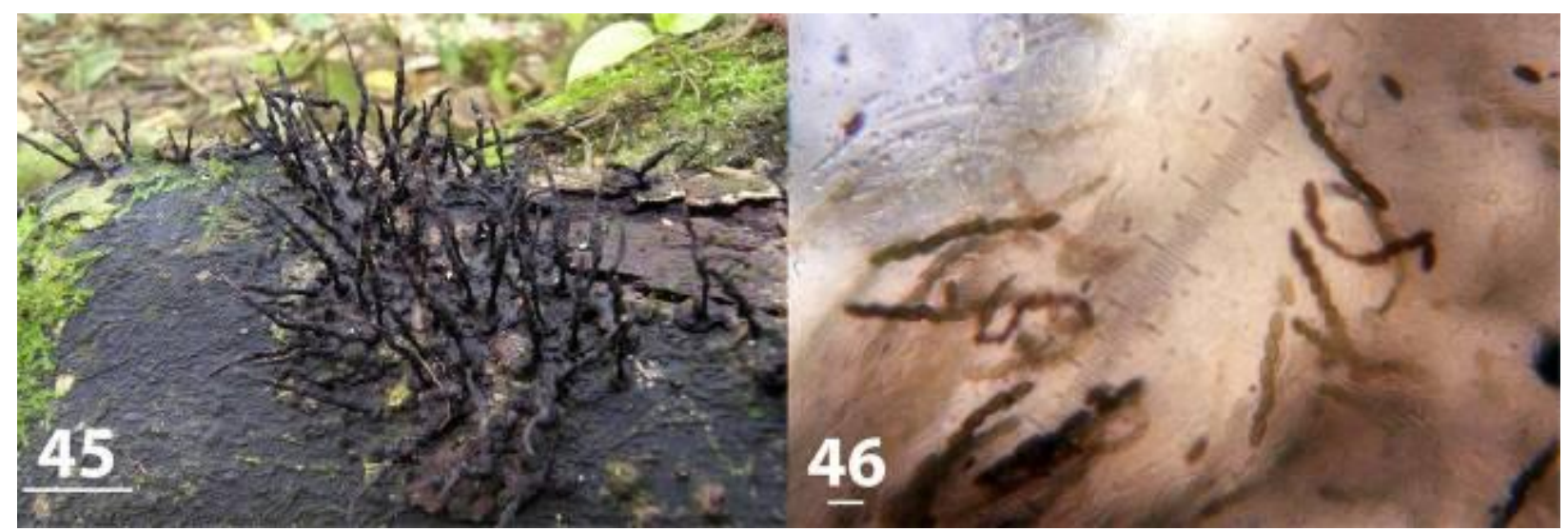

Figs 45-46 - Xylaria subcoccophora. 45 Apothecia in environment. 46 Spores in water. - Bars fig $45=2 \mathrm{~cm}-$ fig $46=15 \mu \mathrm{m}$.

\section{Discussion}

The fruiting bodies of the collection we studied and described were in the conidial stage; the ascogenous form, which is the evolution (we did not observe), presents the same appearance, but is entirely blackish brown, with the surface of the terminations rough or slightly nodulose due to the presence of the perithecia, cracking around them [Dennis (1961), as Xylosphaera multiplex (Kunze) Dennis]. In an Italian collection we carried out on decaying wood of Carpinus, in the conidial stage also some perithecia were noted, with ascospores $9-10 \times 4.5-5 \mu \mathrm{m}[9-12$ $\times$ 4-4.5 $\mu \mathrm{m}$, Dennis 1956, 9-10(-11) × 3.5-4.5 $\mu \mathrm{m}$, Dennis 1961, (9-)10-11(-12) × 4.5-5 $\mu \mathrm{m}$, Bertault 1984], irregularly elliptical, with one thinned end, one side flattened, dark brown and without germinal slit. $X$. multiplex is quite easy to recognize basing on the shape and the relevant dimensions of the fructifications; it recalls in appearance the most common and widespread $X$. hypoxylon (L.: Fr.) Grev. (of which appears to be a luxuriant form), generally not over $50 \mathrm{~mm}$ high, which produces longer fusiform conidia $(10-12 \times 2-3$ $\mu \mathrm{m})$ and larger ascospores, $12-14 \times 5-6 \mu \mathrm{m}$ (Medardi 2006). Dennis (1956) cites $X$. multiplex var. microsperma (Speg.) Dennis, with simple or branched, blackish clavulae, in which the stalk is not always clearly manifest, producing ascospores 6-9 6 3-4 $\mu \mathrm{m}$; according to Dennis (1956), this variety is scarcely distinguishable from the base form. In literature other Xylaria with arborescent outline are described, widespread not only in tropical or equatorial areas. Among them, $X$. coccophora Mont. has single clavulae, forked or branched, up to $40 \mathrm{~mm}$ high, of nodulose appearance by the protrusion of the perithecia, initially covered by a thin sulphur-yellow layer, with ascospores $8-10 \times 3.5-5 \mu \mathrm{m}$ (Dennis 1956) $[10-11(-13) \times(3.5-) 4(-4.5) \mu \mathrm{m}$, San Martín \& Lavín 2001]; X. furcata Fr., whose outline is of a small tree without leaves, up to $100 \mathrm{~mm}$ high and with "branches" of about 1 $\mathrm{mm}$ diam., covered by the perithecia, which produces ascospores 4-5 $\times 2 \mu \mathrm{m}$, Dennis 1956 (5-6 × 1-3 $\mu \mathrm{m}$, Bertault 1984); X. louisii (Dennis) D. Hawksw., with dark clavulae, several times furcate, stalked, similar in shape to a ciborium or a candelabrum with several arms, rough in the upper part due to the protrusion of the perithecia and with hairy stalk, forming fusoid ascospores 20-28 $\times 3.5-$ $4.5 \mu \mathrm{m}$, one side flattened [Dennis (1961), as. Xylosphaera louisii Dennis]; X. pterula Bertault with stalked clavulae, densely branching in thin and flat endings, up to $40 \mathrm{~mm}$ high and totally blackish, but with whitish apex if in the conidial stage, which forms pale brown ascospores 12-13 $\times$ 5-7 $\mu \mathrm{m}$ (Bertault 1984). X. coccophora, X. furcata and X. louisii are peculiar to tropical or equatorial environments, while $X$. pterula fruits on wood of Sambucus in continental environments.

Xylaria subcoccophora F. San Martín \& P. Lavín, in San Martín, Lavín \& Rogers, Mycotaxon 79: 355 (2001) 

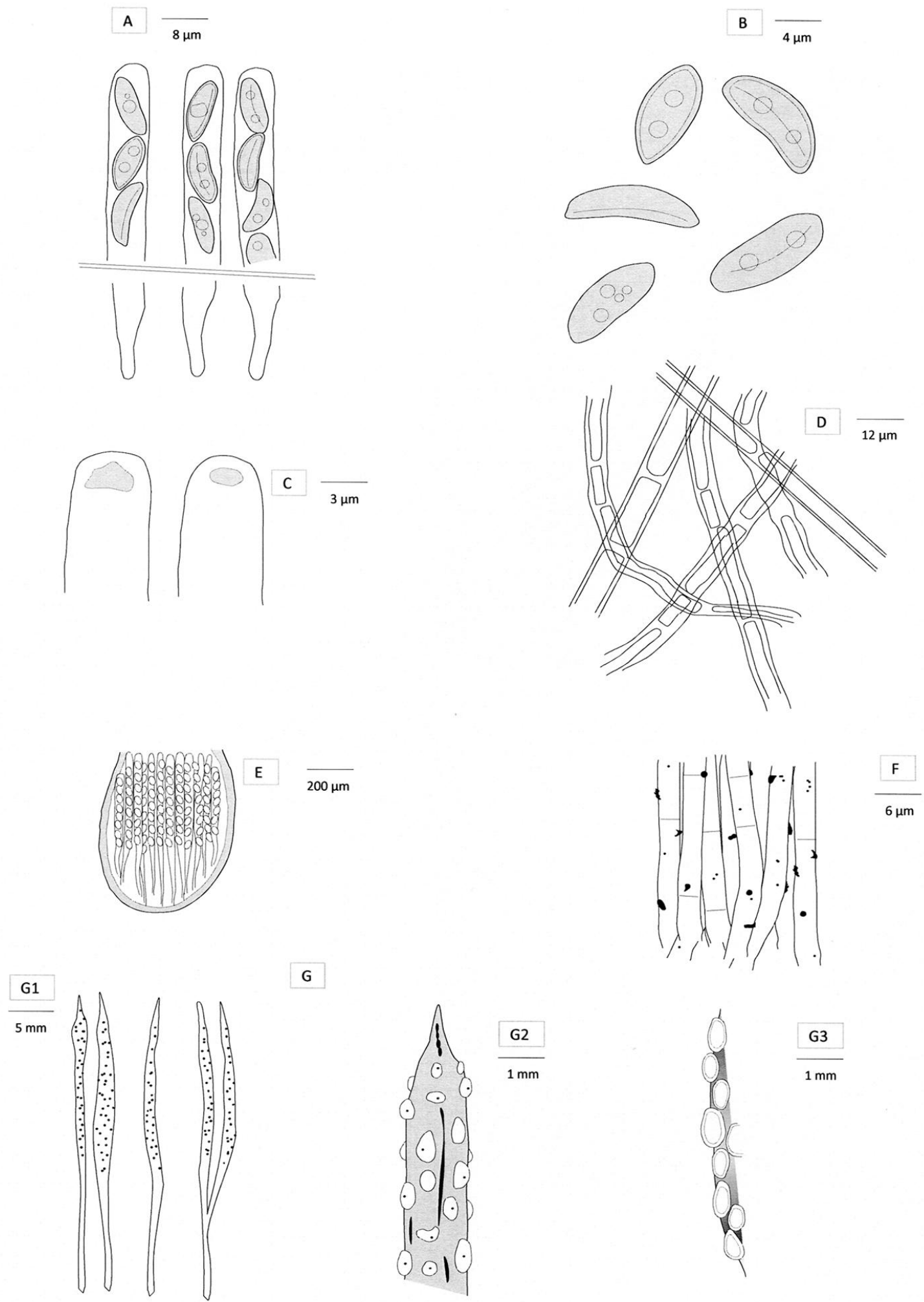

Fig. 47 - Xylaria subcoccophora. A Asci with ascospores. B Released ascospores. C Asci (details of the apical apparatus). D Structure of the stroma. E Perithecium (details). F Structure of the cortical tissue. G Clavulae (G1 General outline. G2 Particular. G3 Vertical partial section of one clavula). 
Ascocarp made up by a stalked clavula, 1.5-2 mm diam. and 15-30 mm high. Clavulae single or rarely furcate, thread-shaped, cylindrical, straight or slightly sinuous, with nodulose appearance due to protrusion of the perithecia; apex tapered, furrowed, sterile. Surface initially coated by a thin whitish crust soon deciduous, then entirely blackish, with some weak longitudinal furrow among the perithecia. In section, perithecia arranged in a single layer, contained in a white or whitish stroma and slightly protruding on the surface. Stalk sterile, smooth, more or less long, slightly dilated at the top where it joins the clavula and near the base. Consistency carbonaceous and brittle in the cortical tissue, fibrous in the stroma. Perithecia globosepapillate or slightly elongated, smooth, blackish, $0.5-0.8 \times 0.5-0.8 \mathrm{~mm}$.

Ascospores 9-11.5 × 3-4.5 $\mu \mathrm{m}[(9-$ )10-11(-11.5) × 4-5 $\mu \mathrm{m}$, San Martín \& Lavín 2001], irregularly ellipsoid-fusiform, curved, asymmetrical, one side flattened, with narrowly rounded ends, thick-walled $(0.8-1 \mu \mathrm{m})$, most of them 2 oil-drops, equipped with a germinal slit more or less rectilinear and not reaching the ends, smooth, dark brown, uniseriate in the asci. Asci 140-175 × 5-6.5 $\mu \mathrm{m}$, cylindrical, with obvious apical apparatus (2-2.5 $\mu \mathrm{m}$ wide), amyloid, 8-spored. Paraphyses absent. Cortical tissue of parallel textura, hyphae about $3 \mu \mathrm{m}$ diam., more or less straight, septate, thick-walled, brown, with the presence of superficial deposits. Stroma of textura intricata, similar to that of the cortex, but with hyphae more curves and more interwoven, septate, 5-6 $\mu \mathrm{m}$ diam., thick-walled (up to $1 \mu \mathrm{m}$ ), hyaline.

Habitat - in groups on degraded wood of frondose tropical / equatorial trees, through the year.

Specimens examined - Dominican Republic, Sosua, P.to Plata, 8 specimens on degraded wood of tropical deciduous trees, 19 Dec 2010, C. Angelini, JBSD 121900.

\section{Discussion}

Other not strictly tropical or equatorial Xylaria have single and erect, more or less thin, nodulose clavulae. Among them, $X$. melanura (Lev.) Sacc., with thread-shaped clavulae $30 \times 0.5 \mathrm{~mm}$ and larger ascospores, 28-32 × 9-11 $\mu \mathrm{m}$ (Dennis 1956); X. juruensis Henn., also fruiting in continental areas, with fusiform clavulae $15-25 \times 2-3 \mathrm{~mm}$, hairy stalk and overlapping ascospores, $10-12 \times 4-5.5 \mu \mathrm{m}$ (Medardi 2006); X. rhizomorpha (Mont.) Mont., with very long thread-shaped clavulae (about $2 \mathrm{~mm}$ diam.) and smaller ascospores, 5 $\times 2.25-2.5 \mu \mathrm{m}$ (Dennis 1956); X. coccophora Mont., with cylindrical-tapered clavulae, single or branched, up to $40 \mathrm{~mm}$ high, at first coated on the top by a clayey yellow-brownish layer, with ascospores 8-10 × 3-3.5 $\mu \mathrm{m}$ (Dennis 1956) $[10-11(-13) \times(3.5-) 4(-4.5) \mu \mathrm{m}$, San Martín \& Lavín 2001]; X. rickii Theiss., with clavule cylindrical-compressed up to $70 \times 4$ $\mathrm{mm}$ and larger ascospores, 18-25 $\times$ 5-7 $\mu \mathrm{m}$, (Dennis 1956); X. compressa Pat. \& Gaillard, continental, with thread-shaped clavulae 30 $40 \times 1-3 \mathrm{~mm}$ and larger ascospores, $12-17 \times 5$ $5.5 \mu \mathrm{m}$, (Bertault 1984); X. carpophila (Pers. : Fr.) Fr., typically on decaying fruits of Fagus, with thread-shaped clavulae $50-80 \times 2-3 \mathrm{~mm}$ and ascospores 10-13 × 3-3.5 $\mu \mathrm{m}$ (Medardi 2006); X. scopiformis (Mont. ex P. Joly) T. Schumach., on wood of Pistacia lentiscus in the Mediterranean area, with long cylindrical clavulae $10-40 \times 1-2 \mathrm{~mm}$ and ascospores 7-12 $\times 3-5 \mu \mathrm{m}$ (Bertault 1984); X. filiformis (Alb. \& Schwein. : Fr.) Fr., continental, on decaying leaves, with thread-shaped clavulae up to 100 $\mathrm{mm}$ high and larger ascospores, 12.5-17 $\times 5$ $6.5 \mu \mathrm{m}$ (Medardi 2006).

\section{Acknowledgements}

We wish to deeply thank F. Jimenez, A. Veloz and R. Garcia (Jardín Botánico Nacional dr. Rafael Ma. Moscoso - Santo Domingo Rep. Dominicana) for their interest in encouraging the study of the fungi of the Dominican Republic and for their active cooperation in putting at our disposal material in the Herbarium of the Botanical Garden of Santo Domingo, and B. Peguero (Jardín Botánico Nacional Santo Domingo) for the precious notices about the environmental vegetation and the arboreal species. 


\section{References}

Ahti $\mathrm{T}$, Dissing $\mathrm{H}$, Eckblad FE, Gjærum $\mathrm{H}$, Gramno A, Kers L, Knudsen H, Læssøe T, Lange M, Lundqvist N, Ohenoja E, Ryman S, Ryvarden L, Schumacher T, Vesterholt J, Whalley AJS. 2000 Nordic Macromycetes, vol. 1, Ascomycetes. Nordsvamp, Kopenhagen.

Bertault R. 1984 - Xylaires d'Europe et d'Afrique du nord. Bull. Soc. Myc. Fr. 100 (2), 141-175.

Calonge FD, Mata M, Umaña L. 2006a Adiciones y correcciones al catálogo de Ascomycota (Fungi) de Costa Rica, con especial referencia al género Scutellinia. Bol. Soc. Micol. Madrid 30, 25-34.

Calonge FD, Mata M, Umaña L. 2006b - El género Phillipsia (Ascomycota) en Costa Rica, con una clave para identificar las especies. Bol. Soc. Micol. Madrid 30, 35-42.

Carrol GC. 1964 - Pyrenomycetes, mainly Xylariaceae, from some South Pacific islands. Bot. Tidschk. 59 (4), 301-310.

Denison WC. 1965 - Central American Pezizales. I. A new genus of the Sarcoscyphaceae. Mycologia 57, 649656.

Dennis RWG. 1956 - Some xylarias of tropical America. Kew Bulletin 11, 401-444.

Dennis RWG. 1957 - Further notes on tropical American Xylariaceae. Kew Bulletin 12, 297-332.

Dennis RWG. 1961 - Xylarioideae and Thamnomycetoideae of Congo. Bull. Jardin Bot. État Brux. 31, 109-154.

Dennis RWG. 1963 - Hypoxyloideae of Congo. Bull. Jardin Bot. État Brux. 33, 317-343.

Dennis RWG. 1981 - British Ascomycetes. J. Cramer, Vaduz.

Douanla-Meli C, Langer E. 2005 - Notes on Discomycetes (Helotiales, Pezizales): new species and new records from Cameroon. Mycotaxon 92, 223-237.

Ellis JB, Everhart BM. 1887 - Synopsis of the North American species of Xylaria and Poronia (continued). The Journal of Mycology 3, 109-113.

Gamundí IJ. 1956 - El genero Scutellinia en la Argentina. Contribuciones Cientificas Serie Botanica 1 (2), 68-95.

Gamundí IJ. 1975 - Fungi, Ascomycetes, Pezizales. Flora criptogamica de Tierra del Fuego 10 (3), 1-181.

Hansen K, Pfister DH, Hibbett DS. 1999 Phylogenetic relationships among species of Phillipsia inferred from molecular and morphological data. Mycologia 91(2), 299-314.

Ju YM, Rogers JD. 1996 - A revision of the genus Hypoxylon. Mycologia Memoir 20, 1-365.

Ju YM, Rogers JD, San Martín F. 1997 - A revision of the genus Daldinia. Mycotaxon 61, 243-293.

Kobayasi Y, Otani Y. 1971 - Enumeration of the Sarcoscyphaceae and Scutellinia (Humariaceae). Bull. Nat. Sci. Mus. Tokyo 14 (3), 401-423.

Le Gal M. 1953 - Les Discomycetes de Madagascar. Prodr. Fl. Mycol. Madag. 4, 1-465.

Le Gal M. 1967 - Validation de plusieurs taxa. Bull. Soc. Myc. Fr. 83, 356-358.

Le Gal M. 1969 - Contribution a la connaissance du genre Scutellinia (Cooke) Lamb. emend. Le Gal $\left(2^{\circ}\right.$ étude). Bull. Soc. Myc. Fr. 84, 375380.

Le Gal M. 1971 - Contribution a la connaissance du genre Scutellinia (Cooke) Lamb. emend. Le Gal. ( $3^{\circ}$ étude). Bull. Soc. Myc. Fr. 87, 433-440.

Matočec N, Antonić O \& Mrvoš D. 1995 The genus Scutellinia (Pezizales, Ascomycotina) in Croatia: preliminary part. Nat. Croat. 4 (1), 1-58.

Medardi G. 2006 - Atlante fotografico degli Ascomiceti d'Italia. A.M.B. Fondazione Centro Studi Micologici, Vicenza.

Moravec J. 1978 - Fungi of Kilimanjaro, I. Discomycetes, Pezizales. Česká Mykologie 32, 70-78.

Moravec J. 1997 - Discomycetes of Madagascar - I. Phillipsia ranomafanensis sp. nov. and ascospore sculpture of Cookeina colensoi proved by SEM (Disco- 
mycetes, Pezizales, Sarcoscyphaceae). Czech Mycol. 50, 21-33 (+ 5 tables).

Pant DC, Tewari VP. 1974 - Ascomycetes of India. Transactions of the British Mycological Society 63, 499-502.

Pfister DH, Kaushal R. 1984 - Cookeina indica, a new species from India with a key to the species of Cookeina. Mycotaxon 20, 117-121.

Rogers JD. 1984 - Xylaria cubensis and its anamorph Xylocoremium flabelliforme, Xylaria allantoidea, and Xylaria poitei in continental United States. Mycologia 76, 912-923.

Rogers JD. 1986 - Provisional keys to Xylaria species in continental United States. Mycotaxon 26, 85-97.

Rogers JD, Samuels GJ. 1986 - Ascomycetes of New Zealand 8. Xylaria. New Zealand Journal of Botany 24, 615-650.

Saccardo PA, Traverso GB, Trotter A. 1889 Sylloge Fungorum omnium hucusque cognitorum. Vol. 8 (Discomyceteae et Phymatosphaeriaceae). Patavii.

San Martín F, Rogers JD, Lavín P, PérezSilva E \& Esqueda M. 1999a - New records of Xylariaceae of Sonora, Mexico. Mycotaxon 71, 129-134.

San Martin FE, Ju YM, Rogers JD. 1999b Algunas especies de Hypoxylon (Pyre- nomycetes, Xylariaceae) de Mexico. Acta Botanica Mexicana 47, 31-53.

San Martín F, Lavín P, Rogers JD. 2001 Some species of Xylaria (Hymenoascomycetes, Xylariaceae) associated with oaks in Mexico. Mycotaxon 79, 337360.

Schumacher T. 1990 - The genus Scutellinia (Pyronemataceae). Opera Botanica 101, 1-107.

Seaver FJ. 1928 - The North American Cupfungi (Operculates). New York.

Trierveiler-Pereira L, Romero AI, Marcon Baltazar J, Loguercio-Leite C. 2009 Addition to the knowledge of Xylaria (Xylariaceae, Ascomycota) in Santa Catarina, Southern Brazil. Mycotaxon 107, 139-156.

Wang YZ. 1997 - Taxonomy of Cookeina in China. Mycotaxon 62, 289-298.

Wang YZ. 2001 - Discomycetes of the Sarcoscyphaceae in Taiwan. Mycotaxon 79, 329-336.

Weinstein RN, Pfister DH. 2002 - A phylogenetic study in the genus Cookeina. Mycologia 94, 673-682.

Zhuang WY. 2003 - Re-disposition of Phillipsia (Pezizales) collections from China. Mycotaxon 86, 291-301. 